Human Wharton's Jelly-Derived Stem Cells Display a Distinct Immunomodulatory and Proregenerative Transcriptional Signature Compared to Bone Marrow-Derived Stem Cells Non Peer-reviewed author version

DONDERS, Raf; BOGIE, Jeroen; RAVANIDIS, Stelios; GERVOIS, Pascal; VANHEUSDEN, Marjan; Marée, Raphaël; Schrynemackers, Marie; Smeets, Hubert J.M.; Pinxteren, Jef; Gijbels, Kristel; Walbers, Sara; Mays, Robert W.; Deans, Robert; Van Den Bosch, Ludo; STINISSEN, Piet; LAMBRICHTS, Ivo; GYSELAERS, Wilfried \& HELLINGS, Niels (2018) Human Wharton's Jelly-Derived Stem Cells Display a Distinct Immunomodulatory and Proregenerative Transcriptional Signature Compared to Bone Marrow-Derived Stem Cells. In: Stem cells and development, 27(2), p. 65-84.

DOI: $10.1089 / \mathrm{scd} .2017 .0029$

Handle: http://hdl.handle.net/1942/25505 


\section{Stem Cells and Development}

Stem Cells and Development: http://mc.manuscriptcentral.com/scd

\section{Human Wharton's jelly-derived stem cells display a distinct immunomodulatory and pro-regenerative transcriptional signature compared to bone marrow-derived stem cells}

\begin{tabular}{|c|c|}
\hline Journal: & Stem Cells and Development \\
\hline Manuscript ID & SCD-2017-0029.R2 \\
\hline Manuscript Type: & Original Research Report \\
\hline Date Submitted by the Author: & 21-Oct-2017 \\
\hline Complete List of Authors: & $\begin{array}{l}\text { Donders, Raf; Universiteit Hasselt Faculteit Geneeskunde en } \\
\text { Levenswetenschappen, Biomedical Research Institute } \\
\text { Bogie, Jeroen; Universiteit Hasselt Faculteit Geneeskunde en } \\
\text { Levenswetenschappen, Biomedical Research Institute } \\
\text { Ravanidis, Stylianos; Universiteit Hasselt Faculteit Geneeskunde en } \\
\text { Levenswetenschappen, Biomedical Research Institute } \\
\text { Gervois, Pascal; Biomedical Research Institute - Hasselt University, } \\
\text { Morphology } \\
\text { Vanheusden, Marjan; Universiteit Hasselt Faculteit Geneeskunde en } \\
\text { Levenswetenschappen, Biomedical Research Institute } \\
\text { Marée, Raphaël; Universite de Liege, GIGA Bioinformatics Core Facility } \\
\text { Schrynemackers, Marie; Universite de Liege, GIGA Bioinformatics Core } \\
\text { Facility } \\
\text { Smeets, Hubert; Maastricht Universitair Medisch Centrum+, Department of } \\
\text { Genetics and Cell Biology, Research School GROW and CARIM } \\
\text { Pinxteren, Jef; ReGenesys BVBA, Bio-Incubator Leuven } \\
\text { Gijbels, Kristel; ReGenesys BVBA, Bio-Incubator Leuven } \\
\text { Walbers, Sara; ReGenesys BVBA, Bio-Incubator Leuven } \\
\text { Mays, Robert; Athersys Inc, Department of Regenerative Medicine } \\
\text { Deans, Robert; Athersys Inc, Department of Regenerative Medicine } \\
\text { Van Den Bosch, Ludo; Katholieke Universiteit Leuven, VIB, Laboratory of } \\
\text { Neurobiology, Experimental Neurology } \\
\text { Stinissen, Piet; Universiteit Hasselt Faculteit Geneeskunde en } \\
\text { Levenswetenschappen, Biomedical Research Institute } \\
\text { Lambrichts, Ivo; Biomedical Research Institute - Hasselt University, Group } \\
\text { of Morphology } \\
\text { Gyselaers, Wilfried; Ziekenhuis Oost-Limburg - Campus Sint Jan, } \\
\text { Gynaecologie-verloskunde; Universiteit Hasselt Faculteit Geneeskunde en } \\
\text { Levenswetenschappen, Biomedical Research Institute } \\
\text { Hellings, Niels; Universiteit Hasselt Faculteit Geneeskunde en } \\
\text { Levenswetenschappen, Biomedical Research Institute }\end{array}$ \\
\hline Keyword: & $\begin{array}{l}\text { Gene Expression, Transcription, Tissue specific stem cells, MAPCs, Bone } \\
\text { Marrow }\end{array}$ \\
\hline $\begin{array}{r}\text { Manuscript Keywords (Search } \\
\text { Terms): }\end{array}$ & $\begin{array}{l}\text { umbilical cord, microarray, MAPC, MSC, neurotrophic factors, immune } \\
\text { modulation }\end{array}$ \\
\hline
\end{tabular}


Abstract:

Mesenchymal stromal cells (MSCs) are multipotent stem cells with immunosuppressive and trophic support functions. While MSCs from different sources frequently display a similar appearance in culture, they often show differences in their surface marker and gene expression profiles. Although bone marrow is considered the 'gold standard' tissue from which to isolate classical MSCs (BM-MSC), MSC-like cells are currently also derived from more easily accessible extra-embryonic tissues such as the umbilical cord. In this study we defined the best way to isolate MSCs from the Wharton's jelly of the human umbilical cord (WJ-MSC) and assessed the mesenchymal and immunological phenotype of BM-MSC and WJ-MSC. Moreover, the gene expression profile of established WJ-MSC cultures was compared to two different bone marrow-derived stem cell populations (BM-MSC and multipotent adult progenitor cells or MAPC $®$ ). We observed that explant culturing of Wharton's jelly matrix is superior to collagenase tissue digestion for obtaining mesenchymal-like cells, with explant isolated cells displaying increased expansion potential. While being phenotypically similar to adult MSCs, WJ-MSC show a different gene expression profile. Gene ontology analysis revealed that genes associated with cell-adhesion, proliferation, and immune system functioning are enriched in WJ-MSC. In vivo transplantation confirms their immune modulatory effect on T cells, similar to BM-MSC and MAPC. Furthermore, WJ-MSC intrinsically overexpress genes involved in neurotrophic support and their secretome induces neuronal maturation of $\mathrm{SH}-\mathrm{SY} 5 \mathrm{Y}$ neuroblastoma cells to a greater extent than BM-MSC. This signature makes WJ-MSC an attractive candidate for cell-based therapy in neurodegenerative and immune-mediated central nervous system disorders such as multiple sclerosis, Parkinson's disease or amyotrophic lateral sclerosis. 


\section{Human Wharton's jelly-derived stem cells display a distinct immunomodulatory and} pro-regenerative transcriptional signature compared to bone marrow-derived stem cells

Raf Donders ${ }^{1}$, Jeroen F.J. Bogie ${ }^{1}$, Stylianos Ravanidis $^{1}$, Pascal Gervois ${ }^{1}$, Marjan Vanheusden $^{1}$, Raphaël Marée ${ }^{2}$, Marie Schrynemackers ${ }^{2}$, Hubert J.M. Smeets ${ }^{3}$, Jef Pinxteren ${ }^{4}$, Kristel Gijbels ${ }^{4}$, Sara Walbers ${ }^{4}$, Robert W. Mays ${ }^{5}$, Robert Deans ${ }^{5}$, Ludo Van Den Bosch ${ }^{6}$, Piet Stinissen $^{1}$, Ivo Lambrichts ${ }^{1}$, Wilfried Gyselaers ${ }^{1,7}$ and Niels Hellings ${ }^{1{ }^{*}}$

${ }^{1}$ Hasselt University, Biomedical Research Institute, Diepenbeek, Belgium

${ }^{2}$ University of Liège, GIGA Bioinformatics Core Facility, Liège, Belgium

${ }^{3}$ Maastricht UMC+, Department of Genetics and Cell Biology, Research School GROW and CARIM, Maastricht, The Netherlands

${ }^{4}$ ReGenesys BVBA, Bio-Incubator Leuven, Heverlee, Belgium

${ }^{5}$ Athersys Inc., Department of Regenerative Medicine, Cleveland, OH, USA

${ }^{6} \mathrm{KU}$ Leuven, Laboratory of Neurobiology, Experimental Neurology and VIB, Center for Brain \& Disease, Leuven, Belgium

${ }^{7}$ Ziekenhuis Oost-Limburg, Campus St. Jan, Genk, Belgium

Running title: transcriptome of WJ- \& BM-derived stem cells

* Corresponding author:

Prof. dr. Niels Hellings

Hasselt University, Biomedical Research Institute

Campus Diepenbeek, Agoralaan building C

3590 Diepenbeek, Belgium

Tel. +32 112692 01; Fax. +32 11269299

niels.hellings@uhasselt.be 
$\underline{\text { List of non-standard abbreviations: }}$

KO-DMEM/F12: Knock Out ${ }^{\text {TM }}$ Dulbecco's modified Eagle's medium with F-12

DMEM-LG: DMEM with low glucose

BM-MSC: human bone marrow-derived MSCs

WJ-MSC: human Wharton's jelly-derived MSCs

MAPC: multipotent adult progenitor cells

NT2/D1: NTERA-2 clone D1 cell line

PD: population doublings

CPD: cumulative population doublings

FC: fold change

GO: gene ontology 


\begin{abstract}
$\underline{\text { Abstract }}$
Mesenchymal stromal cells (MSCs) are multipotent stem cells with immunosuppressive and trophic support functions. While MSCs from different sources frequently display a similar appearance in culture, they often show differences in their surface marker and gene expression profiles. Although bone marrow is considered the 'gold standard' tissue from which to isolate classical MSCs (BM-MSC), MSC-like cells are currently also derived from more easily accessible extra-embryonic tissues such as the umbilical cord. In this study we defined the best way to isolate MSCs from the Wharton's jelly of the human umbilical cord (WJ-MSC) and assessed the mesenchymal and immunological phenotype of BM-MSC and WJ-MSC. Moreover, the gene expression profile of established WJ-MSC cultures was compared to two different-adult MSC bone marrow-derived stem cell populations derived from bone marrow (BM-MSC and multipotent adult progenitor cells or MAPC ${ }^{\circledR}$ ). We observed that explant culturing of Wharton's jelly matrix is superior to collagenase tissue digestion for obtaining mesenchymal-like cells, with explant isolated cells displaying increased expansion potential. While being phenotypically similar to adult MSCs, WJ-MSC show a different gene expression profile. Gene ontology analysis revealed that genes associated with cell-adhesion, proliferation, and immune system functioning are enriched in WJ-MSC. In vivo transplantation confirms their immune modulatory effect on T cells, similar to BM-MSC and MAPC. Furthermore, WJ-MSC intrinsically overexpress genes involved in neurotrophic support and their secretome induces neuronal maturation of SH-SY5Y neuroblastoma cells to a greater extent than BM-MSC. This signature makes WJ-MSC an attractive candidate for cell-based therapy in neurodegenerative and immune-mediated central nervous system disorders such as multiple sclerosis, Parkinson's disease or amyotrophic lateral sclerosis.
\end{abstract}




\section{$\underline{\text { Introduction }}$}

Mesenchymal stromal cells (MSCs) represent a population of multipotent progenitor cells defined by their unique capacity to self-renew and differentiate into typical mesenchymal cell types such as osteoblasts, adipocytes, and chondrocytes [1,2]. Classically, MSCs were isolated from bone marrow (BM-MSC) and characterized as a plastic adherent, fibroblast-like cell population with clonogenic colony forming ability, distinguishing them from hematopoietic cells $[3,4]$. Aside from their supportive function during haematopoiesis, MSCs secrete a variety of growth factors, immunomodulatory cytokines, and other trophic mediators, which makes them an attractive therapeutic strategy for applications in inflammatory and cytodegenerative conditions [5-7]. Because the isolation yield as well as in vitro expansion efficiency and differentiation potential of BM-MSC is often limited [8-12], isolation of MSC-like cells from other tissues of adult [13-15] and fetal [16-18] origin is being explored.

Extra-embryonic tissues are of great interest for stem cell isolation, as they are an abundant source for cells without ethical concerns. Several studies indicate that stromal cells derived from the umbilical cord matrix or Wharton's jelly (WJ-MSC) show MSC-like features, including adherence to plastic substrates, and a similar surface phenotype and differentiation capacity [19-21]. Furthermore, WJ-MSC display immune regulatory properties [22-24] and improve tissue regeneration in several disease models $[25,26]$. Interestingly, previous studies defined that cells from extra-embryonic/fetal origin are superior to adult MSC, showing broader differentiation potential, enhanced expansion potential, and higher cell isolation yields $[10,27,28]$. Accordingly, they are presented as an intermediate between embryonic stem cells and adult MSC-like stem cells [29], being derived from a more primitive tissue source than adult MSC. In contrast, other studies suggest that MSC-like cells derived from different tissues are similar, because they originate from a common progenitor cell [30-32]. 
While MSC-like cells from different tissue sources share a substantial degree of similarity in their phenotype, variation in marker expression profile and lineage-specific commitment have been reported $[33,34]$. As such, it is questionable whether cells from different tissues are truly similar stem cells. More likely, they show a gene expression profile related to their functions in the tissue of origin.

In this study, our aim was to define the relationship between Wharton's jelly and adult bone marrow-derived stem cell populations and to describe the unique gene expression signatures of the perinatal WJ-MSC. We first compared two isolation methods for obtaining Wharton's jelly stromal cells, being the enzymatic digestion of cord matrix and micro-dissected tissue fragment cultures (explants). Next, our established WJ-MSC cultures were morphologically and phenotypically compared to BM-MSC. Both cell types were assessed for their growth characteristics, mesenchymal differentiation capacity, and surface marker expression. Next, we performed gene expression profiling of WJ-MSC compared to bone marrow-derived MSCs and multipotent adult progenitor cells (MAPC). Ingenuity pathway analysis was used to determine the molecular signature of the differentially expressed genes in WJ-MSC. Collectively our data show that WJ cells resemble BM-derived MSCs in culture, but differ at the transcriptional level, with WJ cells overexpressing immune regulatory molecules and neurotrophic factors. In vivo, WJ- but also BM-MSC and MAPC exert local immune modulatory effects on $\mathrm{T}$ cells after subcutaneous transplantation in acute rat experimental autoimmune encephalomyelitis. Furthermore, conditioned medium of WJ-MSC more potently induced neurite outgrowth of differentiated SH-SY5Y compared to BM-MSC. These findings indicate that stem cells derived from the Wharton's jelly are a different type of MSC displaying intrinsic immune modulatory and trophic support functions. These characteristics make WJ-MSC a promising candidate for therapeutic application in inflammation driven neurodegenerative diseases. 


\section{Materials and methods}

\section{Ethical approval}

The collection and experimental use of human cells and tissues was approved by the Medical Ethical Committees of Hasselt University and Ziekenhuis Oost-Limburg (Genk). Umbilical cord tissues were obtained from cesarean sections after informed consent. Animal experiments were performed in accordance with institutional guidelines and are approved by the Hasselt University Ethical Committee for Animal Experiments.

\section{Isolation and culture of WJ-MSC}

Human umbilical cords $(\mathrm{n}=10)$ were obtained aseptically from full-term uncomplicated pregnancies with planned cesarean section and processed for stem cell isolation within 24 hours. Cells were isolated using the explant isolation method, as previously described [33], with minor modifications. Cord blood was removed and the remaining tissue was aseptically stored in sterile phosphate-buffered saline (PBS; Lonza, Verviers, Belgium) supplemented with $1 \%$ penicillin-streptomycin $\left(\mathrm{P} / \mathrm{S} ; 10.000: 10.000\right.$; Gibco ${ }^{\mathrm{TM}}$; ThermoFisher Scientific, Waltham, MA, USA) and $0.2 \%$ Fungizone $^{\circledR}\left(250 \mu \mathrm{g} / \mathrm{ml}\right.$; Gibco $\left.{ }^{\mathrm{TM}}\right)$. Tissues were kept in PBS during processing. First, the umbilical arteries and vein were removed and the remaining matrix was cut into $\pm 2 \mathrm{~mm}^{3}$ fragments (explants). Next, the explants were cultured in Knock Out $^{\mathrm{TM}}$ Dulbecco's modified Eagle's medium with F-12 (KO-DMEM/F12; Gibco ${ }^{\mathrm{TM}}$ ) supplemented with $1 \% \mathrm{P} / \mathrm{S}, 1 \%$ GlutaMAX $^{\mathrm{TM}}$ (L-glut; $200 \mathrm{mM}$; Gibco ${ }^{\mathrm{TM}}$ ) and $10 \%$ fetal bovine serum (FBS; Biochrom AG, Berlin, Germany). Cultures were kept at $37^{\circ} \mathrm{C}$ in a humidified atmosphere containing $5 \% \mathrm{CO}_{2}$ and were left undisturbed for 10 days, to allow migration of cells from attached explant tissue. Non-attached explants were discarded and medium was renewed every three days. At $80-90 \%$ confluence, cells were harvested using Stempro ${ }^{\circledR}$ accutase $\left(\right.$ Gibco $\left.^{\mathrm{TM}}\right)$. WJ-MSC intended for functional assays were harvested 
between passage 2 and passage 8. For microarray analysis, WJ-MSC RNA ( $n=5)$ was collected at the third passage in TRIzol ${ }^{\mathrm{TM}}$ Reagent (ThermoFisher Scientific) and frozen on dry ice. To compare growth of explant-derived cells in different media, WJ-MSC were harvested from the same cord and cultured in parallel in KO-DMEM/F12 or DMEM with low glucose (1 $\mathrm{g} / \mathrm{L} ;$ DMEM-LG; Gibco $\left.{ }^{\mathrm{TM}}\right)$ containing the supplements described above. Enzymatic isolation was performed as described previously [35], with the difference that blood vessels were removed prior to digestion. To compare isolation methods, both explant and enzymatically isolated cells from the same donor were cultured in DMEM-LG with supplements.

\section{Culture of bone marrow-derived stem cells}

Human bone marrow-derived $\operatorname{MSC}(\mathrm{n}=7)$ were purchased from Lonza and cultured according to manufacturer's instructions. For microarray analysis, BM-MSC RNA (n=5) was collected at the third passage using TRIzol. Human MAPC pellets $(\underline{n}=5$; research grade MultistemMAPC ${ }^{\circledR}$ ) were obtained from ReGenesys (ReGenesys bvba, Leuven, Belgium). For this, MAPC were grown in culture stacks, then harvested and centrifuged after which the pellet was collected in TRIzol and frozen on dry ice. MAPC for transplantation purposes were provided as frozen stocks $(\mathrm{n}=2)$. Cells were immersed in water bath until partially thawed and then inverted in DMEM low glucose $(1 \mathrm{~g} / \mathrm{L})\left(\mathrm{Gibco}^{\mathrm{TM}}\right)$ supplemented with $10 \% \mathrm{FBS}$ $\left(\mathrm{Gibco}^{\mathrm{TM}}\right)$ and centrifuged at $600 \mathrm{~g}$ for 8 minutes. Supernatant was removed and cells were dissolved in new medium for counting. Cells were washed twice, and then suspended in sterile saline solution $(0.9 \%$ sodium chloride; Baxter i.v. fluids, Val d'Hony-Verdifarm, Beringen, Belgium) for animal injection (vide infra).

Culture of NTERA-2 cl.D1 and SH-SY5Y cell lines 
NTERA-2 cl.D1 (NT2/D1) was purchased from LGC standards (Molsheim, France; ATCC ${ }^{\circledR}$ CRL-1973 ${ }^{\mathrm{TM}}$ ) and cultured according to the recommended conditions. The SH-SY5Y neuroblastoma cell line (Sigma-Aldrich, St. Louis, Mo, USA) was grown in DMEM/F12 $\left(\right.$ Gibco $\left.^{\mathrm{TM}}\right)$ supplemented with $2 \mathrm{mM}$ L-glutamine $\left(\mathrm{Gibco}^{\mathrm{TM}}\right), 1 \% \mathrm{P} / \mathrm{S}$ and 10\% FBS which will be referred to as standard SH-SY5Y medium. The cells were seeded at a density of $5 \mathrm{x}$ $10^{3}$ cells $/ \mathrm{cm}^{2}$ and incubated at $37^{\circ} \mathrm{C}$ in a humidified atmosphere containing $5 \% \mathrm{CO}_{2}$. The culture medium was changed every 3-4 days. After reaching 70-80\% confluence, the cells were harvested using $0.05 \%$ Trypsin with EDTA $\left(\mathrm{Gibco}^{\mathrm{TM}}\right)$ and expanded.

\section{Preparation of conditioned medium of MSC subtypes}

In order to prepare the conditioned (secretome-containing) medium of WJ-MSC (CM WJMSC) and BM-MSC (CM BM-MSC) for the neurite outgrowth assay, these cell types were seeded at a density of $2 \times 10^{4}$ cells $/ \mathrm{cm}^{2}$ in their standard culture medium (vide supra). After 24 hours, the medium was changed to $1 \mathrm{ml} / 5 \mathrm{~cm}^{2} \mathrm{SH}-\mathrm{SY} 5 \mathrm{Y}$ medium containing $0.1 \% \mathrm{FBS}$. 48 hours later, the medium was collected, centrifuged at $300 \mathrm{~g}$, aliquoted and stored at $-80^{\circ} \mathrm{C}$ for later use.

\section{Culture kinetics}

The proliferative capacity of WJ-MSC and BM-MSC was assessed by calculating cell doubling kinetics for each passage. Cell numbers were determined by means of FuchsRosenthal hemocytometer counts after trypan-blue exclusion (Biochrom AG). Population doublings (PD) were calculated using the formula $\mathrm{PD}=3.32(\log (\mathrm{nH})-\log (\mathrm{nS}))$, where $\mathrm{nS}$ is the number of seeded cells and $\mathrm{nH}$ the number of harvested cells. To yield cumulative population doubling levels (CPD), the PD value was added to the sum of population doublings of the previous passages: $\mathrm{PD}_{\mathrm{x}}=3.32\left(\log \left(\mathrm{nH}_{\mathrm{x}}\right)-\log \left(\mathrm{nS}_{\mathrm{x}}\right)\right)+\mathrm{PD}_{\mathrm{x}-1}$, with $\mathrm{x}$ being 
the passage number. Cumulative population doublings were calculated over a period of $70 \pm 5$ days. For WJ-MSC, cumulative population doublings were calculated after the first passage, since the initial seeding number was unknown and the number of plastic adherent cells could only be determined after this time point.

Analysis of colony formation

Colony formation was assessed by seeding WJ-MSC in 6-well plates (Greiner Bio-One, Frickenhausen, Germany) at 50 cells $/ \mathrm{cm}^{2}$. Cells were cultured for 10 days, with medium change every 3 days. Then, the cultures were fixed with 4\% paraformaldehyde (PFA; SigmaAldrich) and stained with $0.5 \%$ crystal violet (Sigma-Aldrich) in methanol (VWR, Heverlee, Belgium). After washing twice with PBS and air-drying, colony formation was examined with a Primo Vert phase contrast microscope (Carl Zeiss, Jena, Germany).

\section{Multi-lineage differentiation}

Adipogenic, osteogenic, and chondrogenic differentiation of both BM-MSC and WJ-MSC was performed using the corresponding hMSC differentiation bullet kits ${ }^{\circledR}$ from Lonza, according to the manufacturer's instructions. Subsequent histochemical analysis was performed as previously described [33].

\section{Flow cytometry}

WJ-MSC and BM-MSC were harvested, washed with FACS buffer (PBS supplemented with $2 \%$ FBS) and incubated in the dark for 30 minutes at $4^{\circ} \mathrm{C}$ with fluorescently labeled antibodies (see Table S1) or corresponding isotype controls. Stained samples were washed and analyzed on a FACSCalibur instrument using CellQuest software (BD Biosciences, Erembodegem, Belgium). 


\section{Microarray analysis}

For transcriptome analysis, total RNA from five different donors of WJ-MSC, BM-MSC and MAPC was isolated using the MagMAX ${ }^{\mathrm{TM}}-96$ for Microarrays Total RNA Isolation Kit (Ambion ${ }^{\circledR}$; ThermoFisher ScientificLife Technologies). Sample quality and concentration were measured using the Agilent 2100 bioanalyzer (Agilent Technologies) and NanoDrop ND-1000 spectrophotometer (NanoDrop Technologies) respectively. Next, RNA was converted to cDNA, fragmented and labeled, and subsequently hybridized to Affymetrix GeneChip Human Gene 1.0 ST arrays using the Ambion WT Expression Kit and GeneChip WT Terminal labeling and hybridization kits, carried out in a GeneChip hybridization oven 645 (all Affymetrix UK Ltd.). Hybridized chips were stained and washed in a GeneChip fluidics station 450 and scanned using a GeneChip Scanner 3000 7G (both Affymetrix). All steps were carried out according to standard Affymetrix protocols. Quality control was performed using GeneChip Operating software (GCOS 1.4; Affymetrix). Scanned images were visually inspected and raw intensity CEL files were generated. Subsequently, Bioconductor packages running under the $\mathrm{R}$ platform were used to analyze the gene expression data [36,37]. Using the oligo package [38], raw intensity files were pre-processed to obtain robust multichip average (RMA) expression values. Next, differences in gene content between two cell types were identified using an unpaired two-sided t-test. Genes were considered differentially expressed with a fold change (FC) cutoff value $\geq 2$ and a BenjaminiHochberg $(\mathrm{BH})$ corrected $\mathrm{p}$ value $<0.05$. Data were visualized in $\mathrm{R}$ as volcano plots and venn diagrams using the limma package [39]. A heatmap was generated using the heatplus package [40] and principal component analysis (PCA) was plotted using the prcomp function. For data visualization, variance-based non-specific filtering was performed using the genefilter package to remove probe sets exhibiting the smallest variations in expression across the 
samples [41]. For pathway analysis, the full unfiltered data sets were used. Gene ontology analysis was performed using QIAGEN's Ingenuity ${ }^{\circledR}$ Pathway Analysis (IPA ${ }^{\circledR}$, QIAGEN Redwood City, www.qiagen.com/ingenuity) and the Database for Annotation, Visualization and Integrated Discovery (DAVID) [42,43]. For both programs, the significance of association between data set and canonical pathway was determined using built-in Fisher's exact test to measure the gene enrichment in annotation terms [44]. Overrepresented biological functions and canonical pathways with a Fisher exact $\mathrm{P}$ value $<0.05$ were considered significant. The raw data files have been deposited in NCBI's Gene Expression Omnibus [45], accessible through GEO Series accession number GSE77685.

\section{Quantitative PCR ( $P P C R)$}

Total RNA from additional stem cell donors and the NT2/D1 cell line was isolated using the High Pure RNA Isolation Kit (Roche Diagnostics, Vilvoorde, Belgium) according to manufacturer's instructions. RNA quality was assessed with a Nanodrop 2000 spectrophotometer (Thermo Scientific, Waltham, MA, USA) according to standard procedures. $1 \mu \mathrm{g}$ of RNA of both microarray samples and additional donors was reverse transcribed to CDNA using the Reverse transcription system (Promega, Leiden, The Netherlands) according to manufacturer's protocol. To validate the microarray results, qPCR was performed using a StepOnePlusTM Real-Time PCR System (Applied Biosystems B; Life Technologies) with universal cycling conditions ( 20 seconds $95^{\circ} \mathrm{C}, 40$ cycles of 3 seconds at $95^{\circ} \mathrm{C}$ and 30 seconds at $60^{\circ} \mathrm{C}$ ). The qPCR reaction was performed in micro AMP Fast Optical 96-well reactions plates (Applied Biosystems B; Life Technologies) and consisted of fast SYBR green master mix (Applied Biosystems B; Life Technologies), $10 \mathrm{mM}$ of forward and reverse primers (Eurogentec, Seraing, Belgium), nuclease-free water (Promega) and $12.5 \mathrm{ng}$ eDNA template in a total reaction volume of $10 \mu 1$. Non-template controls contained 


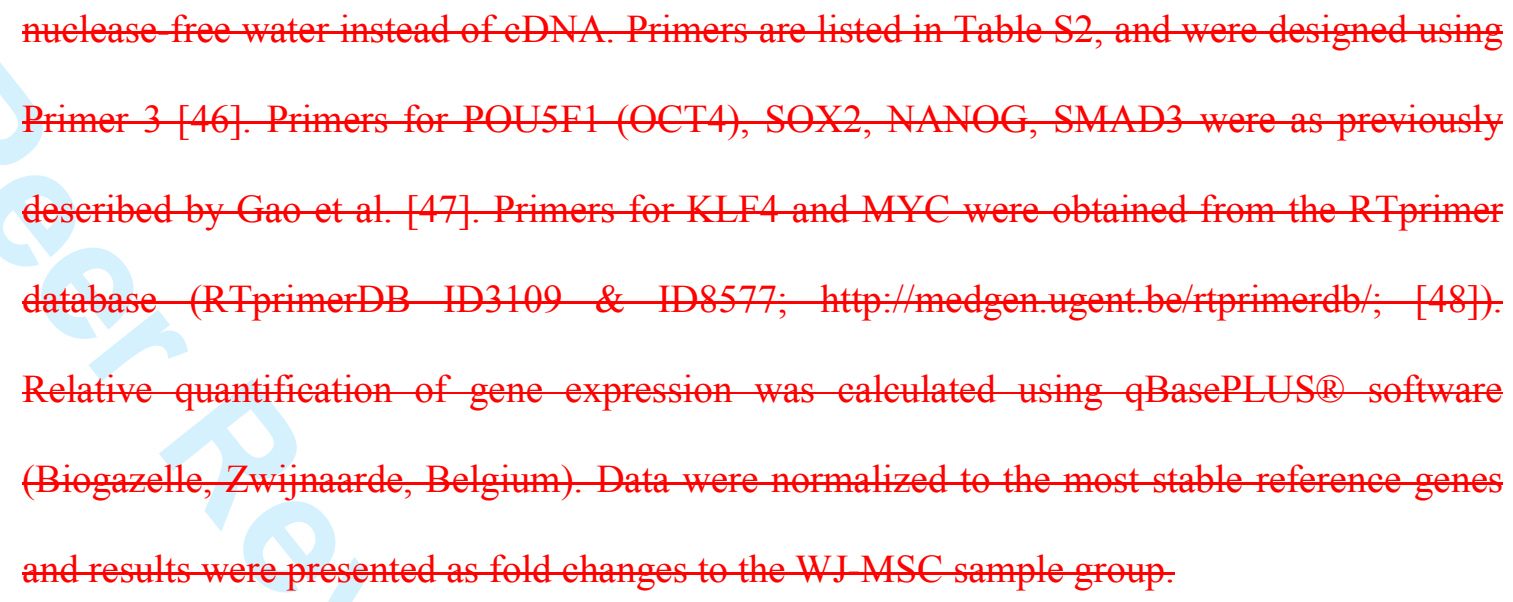

\section{BDNF ELISA}

Supernatant from WJ- and BM-MSC cultures was collected after 7 days and snap frozen. BDNF was detected using the ChemiKine ${ }^{\mathrm{TM}}$ Brain Derived Neurotrophic Factor Sandwich ELISA kit (Chemicon $^{\circledR}$, Millipore, Overijse, Belgium) following the manufacturer's protocols. Data are presented as mean concentration $(\mathrm{pg} / \mathrm{ml})$ from 3 independent experiments.

\section{Neurite outgrowth assay and immunocytochemistry}

To evaluate CM-induced neurite outgrowth, a two-step protocol based on retinoic acid (RA) and BDNF exposure, previously described by Encinas et al. [46] and implemented for CMinduced neurite outgrowth by Gervois et al. [47] was used. SH-SY5Y cells were seeded at a density of $2.5 \times 10^{4}$ cells $/ \mathrm{cm}^{2}$ in standard SH-SY5Y medium on $50 \mu \mathrm{g} / \mathrm{ml}$ collagen type Icoated glass coverslips. After 24 hours, the medium was changed to standard SH-SY5Y medium supplemented with $10 \mu \mathrm{M}$ RA (Sigma-Aldrich) and 1\% FBS instead of $10 \%$ to induce neuronal differentiation. These cells were then kept in culture for 5 days with one medium change after 3 days. Next, the cells were washed with PBS and either CM WJ-MSC, CM BM-MSC or DMEM/F12 supplemented with $50 \mathrm{ng} / \mathrm{ml}$ BDNF or $10 \mu \mathrm{M}$ RA (Immunotools, Friesoythe, Germany) and $0.1 \%$ FBS, was added to the RA-induced SH-SY5Y 
cells to stimulate neuronal maturation. The cells were kept in culture for 7 days and the culture medium or CM was changed every 2-3 days. Samples of each differentiation step were fixed with 4\% PFA and immunostainings were performed according to a standardized protocol for immunofluorescence as described previously [48]. The fully BDNF-differentiated SH-SY5Y cells will be used as a reference for neurite outgrowth of maturated neuroblastoma cells. The influence of RA, BDNF, CM BM-MSC and CM WJ-MSC on neurite outgrowth of SH-SY5Y cells was evaluated by measuring the mean length of the longest neurite on neuritebearing cells that were stained for $1 \mathrm{~h}$ with mouse anti-human $\beta$-III tubulin $(1 / 2000$; clone 2G10; Sigma-Aldrich) using Fiji software [49] with the NeuronJ plugin [50]. At least 100 neurites were counted in each sample. The primary antibody was detected with an Alexa fluor 555-conjugated donkey anti-mouse secondary antibody (30 min incubation, 1/500; clone A31570; Invitrogen ${ }^{\mathrm{TM}}$; ThermoFisher Scientific). The appropriate isotype control (IgG2a; clone MG2a-53; Biolegend, London, UK) was used instead of the primary antibody in an equal concentration $(500 \mathrm{ng} / \mathrm{ml})$ to verify the staining specificity.

\section{Acute EAE induction and subcutaneous stem cell transplantations}

Lewis rats (Janvier Labs, Le Genest-Saint-Isle, France) were housed four per cage, in a controlled environment at $22-24{ }^{\circ} \mathrm{C}$ with $55 \%$ humidity, on a 12 hour light/dark cycle, with ample cage enrichment and access to rodent's chow and water ad libitum. Acute EAE induction was performed as previously described [51]. Briefly, 8 weeks old female Lewis rats were injected subcutaneously in both foot pads with $100 \mu \mathrm{l}$ immunization fluid, consisting of $250 \mu \mathrm{g} / \mathrm{ml}$ guinea pig myelin basic protein (MBP; generated in-house), $2.5 \mathrm{mg} / \mathrm{ml} \mathrm{H37RA}$ heat-killed mycobacterium tuberculosis (Difco, Detroit, MI, USA) and 60 $\mu$ l Complete Freund's adjuvant (Sigma-Aldrich). Stem cell transplantations were performed on -1 dpi, 3 dpi and 6 dpi, via subcutaneous injection in both hind limbs $(100 \mu$ each side, lateral to 
femur) of $1 \times 10^{6}$ human WJ-MSC or $_{2}$ BM-MSC, or MAPC (n=8 animals each) in $200 \mu \mathrm{l}$ of sterile saline solution, or with saline only (control, $n=4 \underline{8}$ ). Nine days post immunization the rats $\_$n=3 per group) were sacrificed by perfusion with Ringer's solution (generated in-house) for lymph node collection.

\section{Restimulation of lymphocytes}

MBP-specific lymphocytes were obtained 9 days post immunization by isolation of the popliteal lymph nodes (LN). LN ( $\mathrm{n}=3$ rats per group) were segregated into single cell suspensions using a $70 \mu \mathrm{m}$ strainer and $5 \mathrm{ml}$ syringe plunger (both Greiner Bio-One). Cell suspensions were separated using ficoll density gradient centrifugation (Histopaque ${ }^{\circledR}-1077$; Sigma-Aldrich) and the mononuclear layer was aspirated for subsequent enrichment of antigen-specific lymphocytes. For this, $2 \times 10^{5}$ cells were cultured for 48 hours in roundbottom 96-well plates (Greiner Bio-One) in restimulation medium, consisting of RPMI 1640 $\left(\mathrm{Gibco}^{\mathrm{TM}}\right)$ supplemented with $0.5 \% \mathrm{P} / \mathrm{S}, 1 \%$ sodium pyruvate $\left(\mathrm{Gibco}^{\mathrm{TM}}\right), 1 \%$ non-essential amino acids $\left(\mathrm{Gibco}^{\mathrm{TM}}\right), 20 \mu \mathrm{M}$ 2-mercaptoethanol (Sigma-Aldrich), 2\% inactivated autologous serum (Lewis rat serum, generated in-house), and $10 \mu \mathrm{g} / \mathrm{ml} \mathrm{MBP.} \mathrm{For} \mathrm{control}$ conditions MBP was omitted.

\section{$\left[{ }^{3} \mathrm{H}\right]$-thymidine incorporation}

The proliferation of LN cells was assayed ex vivo by ${ }^{3} \mathrm{H}$-thymidine incorporation. Following 48 hours of re-stimulation, $1 \mu \mathrm{Ci}\left[{ }^{3} \mathrm{H}\right]$ thymidine (PerkinElmer, Waltham, MA, USA) was added to the lymphocyte cultures for an additional 18 hours. Next, cells were collected with an automated harvester (PerkinElmer) and incorporation of radioactivity was quantified using a $\beta$-plate liquid scintillation counter (PerkinElmer). Relative proliferation is given as 
stimulation index, calculated as the radioactivity of the stimulated sample divided by the average radioactivity of unstimulated samples.

\section{Statistical analysis}

Statistical analyses were performed using Graphpad Prism 5 (GraphPad Software Inc., La Jolla, CA, USA). Data sets were tested for normal distribution using D'Agostino and Pearson omnibus normality test. A one-way analysis of variances (ANOVA, Tukey post hoc) and twotailed unpaired t-test were used to test for significant differences. Results are reported as mean with standard deviation (SD). The Kruskal-Wallis (Dunns post hoc) and Mann-Whitney U analysis were used for data sets which did not pass normality. Results are reported as median with interquartile range (IQR). Differences were considered statistically significant at $\mathrm{P}$ values $<0.05$. 


\section{$\underline{\text { Results }}$}

\section{Explant-derived WJ-MSC show a mesenchymal phenotype}

MSC-like cells were isolated from the Wharton's jelly of the umbilical cord using explant culturing. Approximately seven days after isolation, fragments of cord tissue attached to the culture surface and WJ-MSC started migrating out of the tissue (Figure 1A). After an additional seven days of culture, cells were harvested and seeded for further expansion and characterization. By then, cultures were explant free and cells were grown to $80 \%$ confluence before harvesting. WJ-derived cells were plastic adherent and consisted of a mixed population of smaller triangular shaped cells and larger cells with fibroblast-like morphology (Figure 1B). When cultures were grown to full confluence, WJ-MSC became spindle-shaped and formed colonies (Figure 1C). In addition, cells were able to form colonies when cultured at low density (Figure 1C, inset). WJ-MSC cultures kept growing for $23.4 \pm 1.8 \mathrm{CPD}$ and 81.0 \pm 7.3 days until replicative senescence occurred. Of note, culturing WJ-MSC in KODMEM/F12 resulted in higher growth rates compared to parallel cultures in DMEM-LG (Figure S1A).

An alternative way to isolate cells from the Wharton's jelly comprises the enzymatic digestion of the cord matrix to release the cells $[35,52]$. When comparing both isolation methods, we observed that WJ-MSC obtained using the explant approach had a significantly higher growth rate compared to enzymatically isolated cells (parallel cultures; Figure 1D). The latter displayed an aberrant morphology compared to standard cultures, having a large myofibroblast-like appearance (Figure S1B). This was reflected in their MSC marker profile (Figure 1E), showing a decreased CD73 and CD90 expression upon prolonged culture (increasing passage). In addition, replicative senescence occurred more early in enzymatically isolated WJ cells, reflected by a lower growth rate and earlier growth arrest. 
Next, we compared the growth characteristics, phenotype, and differentiation capacity of our established Wharton's jelly explant cultures with those of classical bone marrow-derived MSCs. The cells used for phenotypical characterization were harvested between passage 2 and passage 8 . For culture kinetics analysis, cultures were grown until replicative senescence. To compare cell yield between the two cell types, cumulative population doublings were calculated over a period of $70 \pm 5$ days. In this time frame, all cells were still growing without any signs of replicative decline. Compared to BM-MSC $(n=7)$, our established WJ-MSC cultures (explant isolated + KO-DMEM/F12; $\mathrm{n}=10$ ) showed significant higher CPD after 70 days of culturing (Figure 1F).

Flow cytometry analysis demonstrated that WJ-MSC display a specific set of surface antigens (Table 1). WJ cells expressed the three main mesenchymal markers CD73, CD90 and CD105. All cultures were negative for HLA-DR and the hematopoietic markers CD14, CD19, CD34 and CD45. No expression of the pluripotency factors OCT4, SOX2 and NANOG was detected by flow cytometry or qPCR (Figure S1C\&D respectively). In addition, WJ-MSC expressed several surface adhesion molecules and immunological markers, being either costimulatory or inhibitory in nature. Compared to BM-MSC, they expressed significant higher levels of CD10, CD146, Integrin-a4 (CD49d), ICAM-1 (CD54), CD200 and PD-L2. Furthermore, both cell types expressed HLA class I molecules and co-stimulatory and inhibitory molecules (e.g. HLA-ABC, HLA-E, PD-L1 and TLR-4) involved in immune cell communication. In addition, WJ-MSC expressed low levels of IFN- $\gamma$ R1 (CD119) and CXCR3 (CD183) receptors. Stem cell subpopulation-related markers CD146, CD117, CD271 and CD133 could be found in several samples, yet donor variability was observed for both MSC types, as shown by the high standard errors. Furthermore, WJ-MSC differentiate into the three classical mesenchymal cell types [33]. End stage differentiation analysis by 
immunohistochemistry is shown in Figure S2 for adipocyte, osteoblast and chondrocyte formation.

\section{Transcriptional analysis reveals WJ-MSC as a distinct type of MSC}

Differential gene expression between extra-embryonic WJ-MSC, adult BM-MSC, and MAPC was determined using Affymetrix Genechip microarray analysis. Global differences in gene expression profiles were visualized by unsupervised hierarchical clustering and principal component analysis. As shown in Figure 2A\&B, the biological samples of each cell type cluster together and form separate groups, indicating that functionally distinct stem cell populations were obtained. Based on hierarchical clustering and Pierson's Correlation, WJMSC are a-unique group of MSCsstem cells, more closely related to BM-MSC than MAPC. Furthermore, clustering shows that MAPC are also distinct from BM-MSC. Volcano plots providing an indication for these differences are given in supplementary Figure S3. The number of differentially expressed genes in WJ-MSC (cutoff: false discovery rate 0.05 and Log FC 1) are depicted in Figure 2A inset. Comparing WJ-MSC to BM-MSC, the expression of 795 genes was altered, of which 382 genes were upregulated and 413 genes were downregulated. Compared with MAPC, a total of 1625 genes were altered, of which 797 were upregulated and 828 were downregulated in WJ-MSC. The top 30 most differentially expressed genes within the WJ cells are listed in Table 2 \& 3. Of note, WJ-MSC highly express multiple cell adhesion molecules and cytokines, such as ITGA2, DSG2, DSC3, IL1A, IL1B, IL8 and CD200, compared to BM-MSC and MAPC. A selection of these differentially expressed gene categories is given in Table 4.

Interestingly, WJ-MSC displayed 411 transcripts that were differentially regulated in comparison to both BM-MSC and MAPC (Figure 2A inset), of which are 272 genes upregulated and 106 genes down-regulated. To further elucidate the distinctive gene expression 
profiles, differential gene pools were screened for their related molecular signature using gene ontology and pathway analysis software.

\section{Gene ontology analysis identifies specialized gene expression within WJ-MSC}

To determine the differences between the three cell types, we analyzed their gene expression patterns in more detail. Gene ontology (GO) analysis was performed to link the differentially regulated transcripts with their biological and molecular functions. For the analysis we focused on the WJ group ( $n=411$ transcripts, differentially expressed versus both BM-MSC and MAPC). Enriched canonical pathways and functional groups are summarized in Table 5

\section{and supplementary Table $\mathbf{S} 3 \underline{\underline{2}}$.}

The most predominant of the overrepresented processes and functions of WJ-MSC include those pertaining to cell movement, cell-cell interactions and adhesion, cell death and survival as well as cardiovascular system development and hepatic cell functioning. Additionally, molecules related to embryonic development were enriched. Interestingly, amongst the three stem cell types, no differential expression of pluripotency markers OCT4, SOX2 and NANOG was observed (Table 4). This does not necessarily mean that these transcription factors are not expressed. Indeed, oOur flow cytometry and PCR data indicated a low negative expression of these transcription factors in WJMSC cultures (Figure S1C\&D). In contrast, KLF4 was significantly higher expressed in BM-MSC compared to the other cell types. MAPC on the other hand showed enrichment of genes related to the cell cycle regulatory machinery, including cyclin-dependent kinases, such as $C D K 1$ (see Table 3).

The gene expression signature of WJ-MSC indicates an active cell modulatory potential through cell-cell contact and secretion of molecules 
When focusing on the differentially expressed gene pools within WJ-MSC, a variety of cytokines and trophic factors such as $I L 8, I L 6, I L 1, C X C L 8, B D N F, N T F 3, T G F B 2, V E G F A$, $F G F 2$, and $L I F$ as well as adhesion and immune regulatory molecules, including ICAM1, VCAM1, CD200, COX-2, PD-L1, CD49B, HLA-ABC, HLA-G,HLA-E, and HLA-F were intrinsically overrepresented (Table 4). Moreover, BDNF protein levels were significantly increased in the supernatant of naive WJ cultures compared to bone marrow MSC (Figure 3). $\underline{\text { In contrast, BM-MSC and MAPC overexpressed TLR4 mRNA. Additionally, PTGES and }}$ $\underline{H G F \text { and KLF4 werewaswere found to be specifically increased in BM-MSC and COX-1 was }}$ upregulated in MAPC. Expression of IDO-1, a T cell proliferation inhibitor [53], was not detected.

Additionally, when searching GO databases for increased biological processes and molecular functions within this differentially regulated gene pool of 411 transcripts, pathways involved in cell movement, cell-cell signaling, as well as cellular adhesion were enriched (Table $\mathbf{5} \&$ S3 $\underline{\text { 22). }}$.

\section{Valtidation of microarray results}

To confirm our microarray results, a selection of genes (see Tables 2\&3-4 and Figure 4) was subjected to quantitative expression analysis. Consistent with the microarray profiles, qPCR analysis confirms the distinct expression pattern of 27 genes amongst the three stem cell types (Figure S45). Genes including ICAM1, CD200, BDNF and LIF amongst others were overexpressed in WJ-MSC. Moreover, BDNF levels were significantly increased in the supernatant of naive WJ cultures compared to bone marrow MSC (Figure 53). As with the microarray results, BM-MSC and MAPC O TLRA mRNA. Additionally, PTGES and KIF4 were found to be specifically inereased in BM-MSC and COX 1 was upregulated in MAPC. The mRNA levels of four pluripotency associated transcription factors, namely 
OCT4, SOX2, NANOG and MYC were unaltered between all cell types. Our qPCR data confirm the reliability of our microarray findings.

\section{MSC secretome promotes neurite outgrowth in SH-SY5Y cells}

To verify the neurotrophic activity of WJ- and BM-MSC, conditioned medium was collected and used to mature differentiating neuroblastoma cells (SH-SY5Y). Neurite outgrowth gradually increased during the differentiation process (Figure $\mathbf{4 A - F}$ ) as was also demonstrated quantitatively (Figure 4G). RA treatment $(45.2 \pm 0.4 \mu \mathrm{m})$ significantly increased the mean neurite length compared to controls $(36.38 \pm 4.36 \mu \mathrm{m} ; \mathrm{P}<0.05)$ (Figure 4A, B) but prolonged RA exposure (Figure 4C) did not additionally improved neurite outgrowth $(45.14 \pm 3.6 \mu \mathrm{m})$. Quantification of neurite outgrowth after B-III tubulin staining showed a significant longer mean neurite length $(\mathrm{P}<0.001)$ for cells treated with $\mathrm{CM} B \mathrm{BM}-$ $\operatorname{MSC}(66.79 \pm 3.24 \mu \mathrm{m}), \mathrm{CM}$ WJ-MSC $(90.71 \pm 5.58 \mu \mathrm{m})$ and $\operatorname{BDNF}(82.32 \pm 5.11 \mu \mathrm{m})$ (Figure 4D-F respectively) compared to control, RA-induced, and RA-maturated SH-SY5Y cells (Figure 4A, B and C respectively). BDNF- and CM WJ-MSC-maturated SH-SY5Y cells have significantly longer neurites than CM BM-MSC-maturated cells $(\mathrm{P}<0.01$ and $\mathrm{P}<$ 0.001 respectively). No significant difference in mean neurite length could be observed between CM WJ-MSC and BDNF maturated SH-SY5Y cells.

\section{Subcutaneous stem cell transplantation in acute EAE exerts local immune modulatory effects on $T$ cells}

To verify the immune suppressive phenotype of the stem cells, in vivo transplantation in acute EAE was performed. In order to assess potential effects on peripheral immune cell activation, stem cells were repeatedly transplanted subcutaneously near the immunization site one day before disease induction, and on day 3 and day 6 during EAE immune system priming. On 
day 9 , lymphocytes were harvested from local lymph nodes and assessed for sensitivity to the immunizing antigen. MBP-specific proliferation of LN cells (mainly T cells) was measured and compared between treated and control animals (Figure 5). LN derived T cells from all treatment groups showed a significantly reduced reactivity towards MBP. These data show that WJ-, BM-MSC, and MAPC treated EAE animals exhibited a reduced lymphocyte proliferation upon restimulation with $\mathrm{MBP}$, indicating that local application of stem cells interferes to some extent with their activation. 


\section{$\underline{\text { Discussion }}$}

MSCs are widely investigated as candidates for tissue engineering and cell transplantation in inflammatory degenerative diseases due to their differentiation capacity, their extensive immune modulatory properties as well as trophic support functions [54]. The human umbilical cord has gained much attention over the years as an alternative source of multipotent MSCs. Furthermore, many reports attribute a broader expansion and differentiation potential to these cells than adult tissue-derived stem cells $[10,29]$. To investigate these extensive biological features of umbilical cord-derived WJ-MSC in comparison to adult bone marrow-derived stem cells, we first identified the most optimal method to isolate and expand the WJ-MSC. Afterwards, we assessed their phenotype and defined their whole genome transcriptional profile.

We found that the explant isolation technique was superior as compared to enzymatic culturing. The explant cell morphology more closely resembled that of fibroblast-like MSCs from bone marrow and the cells exhibited better growth rates than their enzymatic counterparts. Moreover, enzymatic cultures presented with earlier growth arrest and the spontaneous appearance of large myofibroblast-like cells. We speculate that this population is induced by the applied isolation procedure itself. In fact, enzymatic isolation has been reported to potentially alter the immunophenotype and functions of the cell [25,55], as well as preselect for endothelial progenitors [56]. In concordance with other studies [57,58], we show that the Wharton's jelly explant method yields lower variability and better growth rates than enzymatic isolation, here performed as collagenase type I digestion. The latter was previously reported to enrich for MSCs [35]. In our hands, a heterogeneous stem cell isolate containing MSC was initially isolated, but expression of MSC markers declined with increasing culture time (passage 5). Similar morphological and marker expression changes were previously reported for senescent BM-MSC [59] or long term cultured BM- and amnion-derived MSC 
[60].Although enzymatic digestion is the fastest way of obtaining cells from the cord matrix [52], explant or whole cord cultures are considered highly enriching for mesenchymal stromal cells, since spontaneous migration out of the tissue needs to occur $[25,33,61]$.

Our further experiments were performed with explant-derived Wharton's jelly stromal cells. Similar to previous reports [26,62], the cells exhibited MSC-like properties based on their culture morphology, ability to differentiate into the classical mesenchymal cell types (bone, fat, cartilage), and their surface marker expression profile. However, we observed subtle differences in expression of immune-related and adhesion molecules. In summary, these findings indicate that explant-derived WJ-MSC express the previously defined mesenchymal phenotype [4], but differ from BM-MSC regarding their cell surface molecules and growth characteristics.

Extra-embryonic tissue-derived stem cells are attributed extended therapeutic properties over adult stem cells [63-65]. To further find evidence for that, we performed a whole genome transcriptional comparison of WJ-MSC to both lineage-restricted (classical BM-MSC) and to non-restricted MAPC. In this way WJ-MSC were compared to adult cells derived from the same tissue but with different stem cell potency (multipotent BM vs pluripotent MAPC). MAPC, which are derived from bone marrow under defined culture conditions, yield a unique population of stem cells, which have the ability to differentiate into cells from all three germ layers, express markers similar to embryonic stem cells, and show higher replicative potential compared to standard MSCs [66-69].

Here, microarray analysis revealed clear transcriptional differences between stem cells derived from Wharton's jelly and bone marrow. Our data indicate that WJ cells overexpress a multitude of factors with pro-regenerative functions related to cell-cell adhesion, immune modulation, and neurotrophic support. It does not imply that in this comparison the bone marrow-derived stem cell populations do not express these factors. Ample in vitro and 
preclinical data is available on their phenotype and regenerative properties [67,70-72]. Moreover, both types of bone marrow-derived cell populations showed a distinct transcriptional profile. Specifically for WJ-MSC, an upregulated expression of antiinflammatory molecules such as e.g. CD200, PD-L1 and non-classical HLAs, along with adhesion molecules such as ICAM1 and VCAM1 was observed. Such molecules have been implemented in the immunosuppressive actions of stem cells both in vitro and in vivo [73,74]. In this study we confirm the immune modulatory activity in vivo, after stem cell administration near the immunization site in Lewis rat EAE. This setup allows for direct assessment of $\mathrm{T}$ cell modulation, and although the intrinsic immune modulatory profile of the three cell types was different, we found no differences in their ability to reduce $\mathrm{T}$ cell proliferation. We observed aIn this regard, the reduction in autoantigen-induced $\mathrm{T}$ cell proliferation for WJ-, BM-MSC, and MAPC, is indicative of indicating an active interplay between these cells and the inflammatory milieu after loeal application(licensing on the spot), and The observed reduced LN proliferation in transplanted animals is suggestive of an effector mechanism involving paracrine signaling, stem cell homing to lymph nodes and activation of immune modulatory actionprocesses and stem cell homing to lymph nodes after subcutaneous implantation. Multiple molecules might be involved in suppression of $\mathrm{T}$ cells and they are not necessarily the same for each cell type. We have previously shown that IDO$\underline{1 \text { expression in WJ-MSC is involved in suppression of T cell proliferation, but only appears }}$ after licensing [53]. Here, IDO was not detected in the naïve (unlicensed) stem cell populations. Moreover, other immune cells in the inflammatory cascade might be affected. It was previously shown for neural precursor cells that their secretome affected antigen presenting cell functioning after subcutaneous injection in EAE [75]. Regarding LN homing, wWEe and others previously showed that WJ-MSC possess the proper trafficking potential for homing to the peripheral lymphoid tissues $[53,76]$. Furthermore, the majority of intravenously 
transplanted cells are trapped in the pulmonary vasculature and spleen. By subcutaneous administration, cell trapping was avoided.

In addition to the expression of immune signaling molecules, we show constitutive higher levels of BDNF secretion in normal WJ-MSC cultures compared to BM-MSC. Previously we demonstrated a similar gene activity pattern in WJ-MSC, together with a beneficial effect on neuroinflammation and neurodegeneration after transplantation in an animal model of multiple sclerosis [53]. Expression of immune suppressive and neurotrophic factors is a crucial feature for triggering endogenous repair pathways $[25,74]$. Hence, the paracrine potential of $\mathrm{WJ}$ - and BM-MSC to induce neurite outgrowth in human SH-SY5Y neuroblastoma cells was investigated. Here, an adapted protocol based on sequential RA- and BDNF-signaling was used [47]. In the experimental setup, RA-treated SH-SY5Y cells were exposed to $\mathrm{CM}$ of $\mathrm{WJ}-\mathrm{MSC}$ or BM-MSC. In parallel, BDNF-induced maturation was included as a positive control. This RA stimulation prior to the addition of CM or BDNF is preferable as it increases the expression of Tyrosine Kinase (TK) A and B receptor, thereby improving the responsiveness for neurotrophins such as BDNF, which was shown to be secreted by the stem cell populations that were used in this study [46,77]. The results described here are in line with Pires et al. [78], who reported that the secretome of BM-MSC and human umbilical cord perivascular cells (HUCPVC) boosts neurite outgrowth of SHSY5Y cells.

Due to the absence of direct contacts between BM-MSC, WJ-MSC and SH-SY5Y cells, the observed effects are solely attributed to the paracrine factors produced by these stem cell populations. BDNF was one of the neurotrophins identified as increased in the secretome of our WJ-MSC cultures and is a well described neurite outgrowth inducer [79], thereby likely responsible for the observed increase in neurite outgrowth. Martins et al. recently showed that BDNF derived from HUCPVC is a significant determinant for axonal outgrowth in rat 
embryonic cortical neurons [80]. They observed enhanced axonal growth upon local CM application, which was lost when BDNF was depleted from the CM by TK receptor blocking. Nevertheless, the neurite outgrowth observed in our setup can also be attributed to other factors than the CM-derived BDNF. In our cultures, the concentration of BDNF secreted by WJ-MSCs and BM-MSCs is less than $400 \mathrm{pg} / \mathrm{ml}$, compared to the positive control containing $50 \mathrm{ng} / \mathrm{ml} \mathrm{BDNF}$, thereby hinting at the involvement of other effector molecules. This hypothesis is in line with Crigler et al. who demonstrated that the effect of BM-MSCproduced BDNF is only partially responsible for the observed effects on SH-SY5Y cells [81]. The involvement of several distinct molecular categories, including neurotrophic and angiogenic growth factors, cytokines, and microvesicles have been reported[64,74,78,82,83]. Likewise, a number of in vivo studies showed that expression of such cytokines and neuroprotective growth factors by WJ-MSC correlates with a beneficial outcome in rat models of Parkinson's disease [84], ischemic stroke ([85,86]), and spinal cord injury [87].

Finally, WJ-MSC display a plethora of other molecules for immunological interaction, cell adhesion and homing (reviewed elsewhere $[62,88]$ ). Importantly, homing capacity together with a reduced co-stimulatory surface profile and immunomodulatory phenotype are essential for effective cell communication and migration towards sites of injury in both autologous or allogeneic application. Similar to the study by Fong et al., we observed comparable results for expression of HLA class I genes, cytokines and adhesion molecules, but we found no expression of pluripotency markers (e.g. OCT4, SOX2, NANOG) in WJ-MSC [63].

Although many tissue-derived stem cells are designated as MSCs, most comparative in vitro studies of stem cells derived from different tissue sources have indicated functional differences in gene and protein expression, postulating the novel stem cell subtype to be better than the other. Plausible reasons for such differences could be (1) no uniform marker set identifies MSCs from all these sources, (2) variations in isolation technique and culture 
medium components [89], or (3) MSCs acquire culture induced differences in cell potency $[89,90]$. In addition, the aseptic collection and processing of tissues is critical in preventing microbial contamination but also stem cell activation through e.g. TLR's [91]. Roobrouck et al. indicated that both phenotype and functional properties of human mesangioblasts, BMMSC and MAPC were partially influenced by the culture conditions [90]. Gatta et al. reported genotypical changes after extended in vitro culturing of WJ-MSC (12 passages) [92]. In this study, both BM-MSC and WJ-MSC were harvested at early passage (passage 3), minimizing the extent of prolonged culturing effects. In addition, all three cell types were cultured in different media inherent to their isolation method. We found a similar picture for umbilical cord MSC as was previously reported by Klingemann et al., who compared the overall transcriptional profiles of umbilical cord and bone marrow derived MSC cultured under the same conditions [93]. Nevertheless, to date, it remains to be determined whether the isolation method used or additional growth factors in culture have a potential impact on the observed expression profile of the WJ cells. Based on our data and others (described above \& $[25,94]$ ), we suggest that the isolation method already selects for a certain cell phenotype, which depending on the amount of physical stress during the handling (e.g. enzymatic cleaving of membrane receptors, mechanical stress of forceps or centrifugation) predestines for the specific gene expression patterns observed later on in cultured cells.

In summary, this study reports the isolation of mesenchymal-like cells from the Wharton's jelly that express a distinct transcriptional signature compared to lineage-restricted and nonrestricted bone marrow-derived stem cells. Overall, our data support the previous notion that WJ-MSC are equipped with potent trophic and immunomodulatory properties, related to their functions in vivo at the fetus-maternal interface $[24,27,73]$. Furthermore, we specifically observed an overrepresentation of immune modulatory and neurotrophic growth factors in 
WJ-MSC, indicating a potential beneficial role for transplantation in neurodegenerative diseases like spinal cord injury, stroke, multiple sclerosis, Parkinson's disease or amyotrophic lateral sclerosis, for which there is currently no cure. 


\section{Acknowledgements}

We thank Goele Willekens, Katrien Wauterickx and Christel Bocken (Hasselt University, Biomedical Research institute), Kristel Gijbels (ReGenesys), Sabina Vanherle and dr. Patrick Lindsey (University Maastricht Genome Center) for their assistance with the stem cell cultures or microarray analysis. Especially, we thank Stephane Plaisance (VIB-BITS) for his advice and support with the pathway analysis software.

\section{Funding}

This research was promoted by grants from the IWT (agentschap voor Innovatie door Wetenschap en Technology), Alma-in-Silico (EMR INT4.-1.3.-2008-03/003), the VIB (Vlaams Instituut voor Biotechnologie), the transnational University Limburg, Hasselt University, and Limburg Sterk Merk. Pascal Gervois is supported by grant number $12 \mathrm{U} 7718 \mathrm{~N}$ of the Fonds Wetenschappelijk Onderzoek Vlaanderen. The funding agencies had no role in study design, data collection and analysis, decision to publish, or preparation of the manuscript.

\section{Author Disclosure Statement}

The authors declare that no competing financial interests exist. 


\section{References}

1. Prockop DJ. (1997). Marrow stromal cells as stem cells for nonhematopoietic tissues. Science 276:71-4.

2. Pittenger MF, AM Mackay, SC Beck, RK Jaiswal, R Douglas, JD Mosca, MA Moorman, DW Simonetti, S Craig and DR Marshak. (1999). Multilineage potential of adult human mesenchymal stem cells. Science 284:143-7.

3. Friedenstein AJ, JF Gorskaja and NN Kulagina. (1976). Fibroblast precursors in normal and irradiated mouse hematopoietic organs. Exp Hematol 4:267-74.

4. Dominici M, K Le Blanc, I Mueller, I Slaper-Cortenbach, F Marini, D Krause, R Deans, A Keating, D Prockop and E Horwitz. (2006). Minimal criteria for defining multipotent mesenchymal stromal cells. The International Society for Cellular Therapy position statement. Cytotherapy 8:315-7.

5. Ghannam S, C Bouffi, F Djouad, C Jorgensen and D Noel. (2010). Immunosuppression by mesenchymal stem cells: mechanisms and clinical applications. Stem Cell Res Ther 1:2.

6. Keating A. (2012). Mesenchymal stromal cells: new directions. Cell Stem Cell 10:709-16.

7. Yagi H, A Soto-Gutierrez, B Parekkadan, Y Kitagawa, RG Tompkins, N Kobayashi and ML Yarmush. (2010). Mesenchymal stem cells: Mechanisms of immunomodulation and homing. Cell Transplant 19:667-79.

8. Le Blanc $\mathrm{K}$ and $\mathrm{O}$ Ringden. (2007). Immunomodulation by mesenchymal stem cells and clinical experience. J Intern Med 262:509-25.

9. Wexler SA, C Donaldson, P Denning-Kendall, C Rice, B Bradley and JM Hows. (2003). Adult bone marrow is a rich source of human mesenchymal 'stem' cells but umbilical cord and mobilized adult blood are not. Br J Haematol 121:368-74.

10. Batsali AK, MC Kastrinaki, HA Papadaki and C Pontikoglou. (2013). Mesenchymal stem cells derived from Wharton's Jelly of the umbilical cord: biological properties and emerging clinical applications. Curr Stem Cell Res Ther 8:144-55.

11. Sethe S, A Scutt and A Stolzing. (2006). Aging of mesenchymal stem cells. Ageing Res Rev 5:91-116.

12. Stenderup K, J Justesen, C Clausen and M Kassem. (2003). Aging is associated with decreased maximal life span and accelerated senescence of bone marrow stromal cells. Bone 33:91926.

13. Kokai LE, K Marra and JP Rubin. (2014). Adipose stem cells: biology and clinical applications for tissue repair and regeneration. Transl Res 163:399-408.

14. Koninckx R, A Daniels, S Windmolders, U Mees, R Macianskiene, K Mubagwa, P Steels, L Jamaer, J Dubois, B Robic, M Hendrikx, JL Rummens and K Hensen. (2013). The cardiac atrial appendage stem cell: a new and promising candidate for myocardial repair. Cardiovasc Res 97:413-23.

15. Liu H, S Gronthos and S Shi. (2006). Dental pulp stem cells. Methods Enzymol 419:99-113.

16. Parolini $O$ and M Caruso. (2011). Review: Preclinical studies on placenta-derived cells and amniotic membrane: an update. Placenta 32 Suppl 2:S186-95.

17. Lindenmair A, T Hatlapatka, G Kollwig, S Hennerbichler, C Gabriel, S Wolbank, H Redl and C Kasper. (2012). Mesenchymal stem or stromal cells from amnion and umbilical cord tissue and their potential for clinical applications. Cells 1:1061-88.

18. McGuckin CP and N Forraz. (2008). Potential for access to embryonic-like cells from human umbilical cord blood. Cell Prolif 41 Suppl 1:31-40.

19. Mitchell KE, ML Weiss, BM Mitchell, P Martin, D Davis, L Morales, B Helwig, M Beerenstrauch, K Abou-Easa, T Hildreth, D Troyer and S Medicetty. (2003). Matrix cells from Wharton's jelly form neurons and glia. Stem Cells 21:50-60.

20. Wang HS, SC Hung, ST Peng, CC Huang, HM Wei, YJ Guo, YS Fu, MC Lai and CC Chen. (2004). Mesenchymal stem cells in the Wharton's jelly of the human umbilical cord. Stem Cells 22:1330-7. 
21. Romanov YA, VA Svintsitskaya and VN Smirnov. (2003). Searching for alternative sources of postnatal human mesenchymal stem cells: candidate MSC-like cells from umbilical cord. Stem Cells 21:105-10.

22. Weiss ML, C Anderson, S Medicetty, KB Seshareddy, RJ Weiss, I VanderWerff, D Troyer and KR McIntosh. (2008). Immune properties of human umbilical cord Wharton's jelly-derived cells. Stem Cells 26:2865-74.

23. Najar M, G Raicevic, HI Boufker, H Fayyad-Kazan, C De Bruyn, N Meuleman, D Bron, M Toungouz and L Lagneaux. (2010). Adipose-tissue-derived and Wharton's jelly-derived mesenchymal stromal cells suppress lymphocyte responses by secreting leukemia inhibitory factor. Tissue Eng Part A 16:3537-46.

24. Bongso A and CY Fong. (2013). The therapeutic potential, challenges and future clinical directions of stem cells from the Wharton's jelly of the human umbilical cord. Stem Cell Rev 9:226-40.

25. Dalous J, J Larghero and O Baud. (2012). Transplantation of umbilical cord-derived mesenchymal stem cells as a novel strategy to protect the central nervous system: technical aspects, preclinical studies, and clinical perspectives. Pediatr Res 71:482-90.

26. Troyer DL and ML Weiss. (2008). Wharton's jelly-derived cells are a primitive stromal cell population. Stem Cells 26:591-9.

27. Can A and S Karahuseyinoglu. (2007). Concise review: human umbilical cord stroma with regard to the source of fetus-derived stem cells. Stem Cells 25:2886-95.

28. Weiss ML and DL Troyer. (2006). Stem cells in the umbilical cord. Stem Cell Rev 2:155-62.

29. Pappa KI and NP Anagnou. (2009). Novel sources of fetal stem cells: where do they fit on the developmental continuum? Regen Med 4:423-33.

30. Bianco P, X Cao, PS Frenette, JJ Mao, PG Robey, PJ Simmons and CY Wang. (2013). The meaning, the sense and the significance: translating the science of mesenchymal stem cells into medicine. Nat Med 19:35-42.

31. Dore-Duffy P. (2008). Pericytes: pluripotent cells of the blood brain barrier. Curr Pharm Des 14:1581-93.

32. Blocki A, Y Wang, M Koch, P Peh, S Beyer, P Law, J Hui and M Raghunath. (2013). Not all MSCs can act as pericytes: functional in vitro assays to distinguish pericytes from other mesenchymal stem cells in angiogenesis. Stem Cells Dev 22:2347-55.

33. Struys T, M Moreels, W Martens, R Donders, E Wolfs and I Lambrichts. (2011). Ultrastructural and immunocytochemical analysis of multilineage differentiated human dental pulp- and umbilical cord-derived mesenchymal stem cells. Cells Tissues Organs 193:366-78.

34. Hass R, C Kasper, S Bohm and R Jacobs. (2011). Different populations and sources of human mesenchymal stem cells (MSC): A comparison of adult and neonatal tissue-derived MSC. Cell Commun Signal 9:12.

35. Schugar RC, SM Chirieleison, KE Wescoe, BT Schmidt, Y Askew, JJ Nance, JM Evron, B Peault and BM Deasy. (2009). High harvest yield, high expansion, and phenotype stability of CD146 mesenchymal stromal cells from whole primitive human umbilical cord tissue. J Biomed Biotechnol 2009:789526.

36. Team RC. (2014). R: A Language and Environment for Statistical Computing.

37. Gentleman RC, VJ Carey, DM Bates, B Bolstad, M Dettling, S Dudoit, B Ellis, L Gautier, Y Ge, J Gentry, K Hornik, T Hothorn, W Huber, S lacus, R Irizarry, F Leisch, C Li, M Maechler, AJ Rossini, G Sawitzki, C Smith, G Smyth, L Tierney, JY Yang and J Zhang. (2004). Bioconductor: open software development for computational biology and bioinformatics. Genome Biol 5:R80.

38. Carvalho BS and RA Irizarry. (2010). A framework for oligonucleotide microarray preprocessing. Bioinformatics 26:2363-7.

39. Smyth GK. (2005). Limma: linear models for microarray data. In: Bioinformatics and Computational Biology Solutions using R and Bioconductor. Gentleman R, V Carey, W Huber, R Irizarry and S Dudoit eds. Springer, New York. pp 397-420. 
40. Ploner A. (2014). Heatplus: Heatmaps with row and/or column covariates and colored clusters.

41. Gentleman R, V Carey, W Huber and F Hahne. (2014). Genefilter: methods for filtering genes from microarray experiments. .

42. Huang da W, BT Sherman and RA Lempicki. (2009). Systematic and integrative analysis of large gene lists using DAVID bioinformatics resources. Nat Protoc 4:44-57.

43. Huang da W, BT Sherman and RA Lempicki. (2009). Bioinformatics enrichment tools: paths toward the comprehensive functional analysis of large gene lists. Nucleic Acids Res 37:1-13.

44. Bogie JF, S Timmermans, VA Huynh-Thu, A Irrthum, HJ Smeets, JA Gustafsson, KR Steffensen, M Mulder, P Stinissen, N Hellings and JJ Hendriks. (2012). Myelin-derived lipids modulate macrophage activity by liver $X$ receptor activation. PLoS One 7:e44998.

45. Edgar R, M Domrachev and AE Lash. (2002). Gene Expression Omnibus: NCBI gene expression and hybridization array data repository. Nucleic Acids Res 30:207-10.

46. Encinas M, M Iglesias, Y Liu, H Wang, A Muhaisen, V Cena, C Gallego and JX Comella. (2000). Sequential treatment of SH-SY5Y cells with retinoic acid and brain-derived neurotrophic factor gives rise to fully differentiated, neurotrophic factor-dependent, human neuron-like cells. J Neurochem 75:991-1003.

47. Gervois P, E Wolfs, Y Dillen, P Hilkens, J Ratajczak, RB Driesen, T Vangansewinkel, A Bronckaers, B Brone, T Struys and I Lambrichts. (2017). Paracrine Maturation and Migration of SH-SY5Y Cells by Dental Pulp Stem Cells. J Dent Res 96:654-662.

48. Gervois P, T Struys, P Hilkens, A Bronckaers, J Ratajczak, C Politis, B Brone, I Lambrichts and W Martens. (2015). Neurogenic maturation of human dental pulp stem cells following neurosphere generation induces morphological and electrophysiological characteristics of functional neurons. Stem Cells Dev 24:296-311.

49. Schindelin J, I Arganda-Carreras, E Frise, V Kaynig, M Longair, T Pietzsch, S Preibisch, C Rueden, S Saalfeld, B Schmid, JY Tinevez, DJ White, V Hartenstein, K Eliceiri, P Tomancak and A Cardona. (2012). Fiji: an open-source platform for biological-image analysis. Nat Methods 9:676-82.

50. Meijering E, M Jacob, JC Sarria, P Steiner, $H$ Hirling and M Unser. (2004). Design and validation of a tool for neurite tracing and analysis in fluorescence microscopy images. Cytometry A 58:167-76.

51. Bogie JF, P Stinissen, N Hellings and JJ Hendriks. (2011). Myelin-phagocytosing macrophages modulate autoreactive T cell proliferation. J Neuroinflammation 8:85.

52. Seshareddy K, D Troyer and ML Weiss. (2008). Method to isolate mesenchymal-like cells from Wharton's Jelly of umbilical cord. Methods Cell Biol 86:101-19.

53. Donders R, M Vanheusden, JF Bogie, S Ravanidis, K Thewissen, P Stinissen, W Gyselaers, JJ Hendriks and N Hellings. (2015). Human Wharton's Jelly-Derived Stem Cells Display Immunomodulatory Properties and Transiently Improve Rat Experimental Autoimmune Encephalomyelitis. Cell Transplant 24:2077-98.

54. Caplan Al. (2007). Adult mesenchymal stem cells for tissue engineering versus regenerative medicine. J Cell Physiol 213:341-7.

55. Salehinejad P, NB Alitheen, AM Ali, AR Omar, M Mohit, E Janzamin, FS Samani, Z Torshizi and SN Nematollahi-Mahani. (2012). Comparison of different methods for the isolation of mesenchymal stem cells from human umbilical cord Wharton's jelly. In Vitro Cell Dev Biol Anim 48:75-83.

56. Corotchi MC, MA Popa, A Remes, LE Sima, I Gussi and M Lupu Plesu. (2013). Isolation method and xeno-free culture conditions influence multipotent differentiation capacity of human Wharton's jelly-derived mesenchymal stem cells. Stem Cell Res Ther 4:81.

57. Iftimia-Mander A, P Hourd, R Dainty and RJ Thomas. (2013). Mesenchymal stem cell isolation from human umbilical cord tissue: understanding and minimizing variability in cell yield for process optimization. Biopreserv Biobank 11:291-8. 
58. Yoon JH, EY Roh, S Shin, NH Jung, EY Song, JY Chang, BJ Kim and HW Jeon. (2013). Comparison of explant-derived and enzymatic digestion-derived MSCs and the growth factors from Wharton's jelly. Biomed Res Int 2013:428726.

59. Wagner W, P Horn, M Castoldi, A Diehlmann, S Bork, R Saffrich, V Benes, J Blake, S Pfister, V Eckstein and AD Ho. (2008). Replicative senescence of mesenchymal stem cells: a continuous and organized process. PLoS One 3:e2213.

60. Pogozhykh O, D Pogozhykh, AL Neehus, A Hoffmann, R Blasczyk and T Muller. (2015). Molecular and cellular characteristics of human and non-human primate multipotent stromal cells from the amnion and bone marrow during long term culture. Stem Cell Res Ther 6:150.

61. De Bruyn C, M Najar, G Raicevic, N Meuleman, K Pieters, B Stamatopoulos, A Delforge, D Bron and L Lagneaux. (2011). A rapid, simple, and reproducible method for the isolation of mesenchymal stromal cells from Wharton's jelly without enzymatic treatment. Stem Cells Dev 20:547-57.

62. Kim DW, M Staples, K Shinozuka, P Pantcheva, SD Kang and CV Borlongan. (2013). Wharton's jelly-derived mesenchymal stem cells: phenotypic characterization and optimizing their therapeutic potential for clinical applications. Int J Mol Sci 14:11692-712.

63. Fong CY, LL Chak, A Biswas, JH Tan, K Gauthaman, WK Chan and A Bongso. (2011). Human Wharton's jelly stem cells have unique transcriptome profiles compared to human embryonic stem cells and other mesenchymal stem cells. Stem Cell Rev 7:1-16.

64. Hsieh JY, HW Wang, SJ Chang, KH Liao, IH Lee, WS Lin, CH Wu, WY Lin and SM Cheng. (2013). Mesenchymal stem cells from human umbilical cord express preferentially secreted factors related to neuroprotection, neurogenesis, and angiogenesis. PLoS One 8:e72604.

65. De Kock J, M Najar, J Bolleyn, F Al Battah, RM Rodrigues, K Buyl, G Raicevic, O Govaere, S Branson, K Meganathan, JA Gaspar, T Roskams, A Sachinidis, L Lagneaux, T Vanhaecke and V Rogiers. (2012). Mesoderm-derived stem cells: the link between the transcriptome and their differentiation potential. Stem Cells Dev 21:3309-23.

66. Jiang Y, BN Jahagirdar, RL Reinhardt, RE Schwartz, CD Keene, XR Ortiz-Gonzalez, M Reyes, T Lenvik, T Lund, M Blackstad, J Du, S Aldrich, A Lisberg, WC Low, DA Largaespada and CM Verfaillie. (2002). Pluripotency of mesenchymal stem cells derived from adult marrow. Nature 418:41-9.

67. Ravanidis S, JF Bogie, R Donders, D Craeye, RW Mays, R Deans, K Gijbels, A Bronckaers, P Stinissen, J Pinxteren and $N$ Hellings. (2015). Neuroinflammatory signals enhance the immunomodulatory and neuroprotective properties of multipotent adult progenitor cells. Stem Cell Res Ther 6:176.

68. Subramanian K, M Geraerts, KA Pauwelyn, Y Park, DJ Owens, M Muijtjens, F Ulloa-Montoya, $Y$ Jiang, CM Verfaillie and WS Hu. (2010). Isolation procedure and characterization of multipotent adult progenitor cells from rat bone marrow. Methods Mol Biol 636:55-78.

69. Ulloa-Montoya F, BL Kidder, KA Pauwelyn, LG Chase, A Luttun, A Crabbe, M Geraerts, AA Sharov, Y Piao, MS Ko, WS Hu and CM Verfaillie. (2007). Comparative transcriptome analysis of embryonic and adult stem cells with extended and limited differentiation capacity. Genome Biol 8:R163.

70. Boozer S, N Lehman, U Lakshmipathy, B Love, A Raber, A Maitra, R Deans, MS Rao and AE Ting. (2009). Global Characterization and Genomic Stability of Human MultiStem, A Multipotent Adult Progenitor Cell. J Stem Cells 4:17-28.

71. Busch SA, JA Hamilton, KP Horn, FX Cuascut, R Cutrone, N Lehman, RJ Deans, AE Ting, RW Mays and J Silver. (2011). Multipotent adult progenitor cells prevent macrophage-mediated axonal dieback and promote regrowth after spinal cord injury. J Neurosci 31:944-53.

72. Burrows GG, W Van't Hof, LF Newell, A Reddy, PA Wilmarth, LL David, A Raber, A Bogaerts, J Pinxteren, RJ Deans and RT Maziarz. (2013). Dissection of the human multipotent adult progenitor cell secretome by proteomic analysis. Stem Cells Transl Med 2:745-57.

73. La Rocca G, R Anzalone, S Corrao, F Magno, T Loria, M Lo lacono, A Di Stefano, P Giannuzzi, L Marasa, F Cappello, G Zummo and F Farina. (2009). Isolation and characterization of Oct- 
4+/HLA-G+ mesenchymal stem cells from human umbilical cord matrix: differentiation potential and detection of new markers. Histochem Cell Biol 131:267-82.

74. Teixeira FG, MM Carvalho, N Sousa and AJ Salgado. (2013). Mesenchymal stem cells secretome: a new paradigm for central nervous system regeneration? Cell Mol Life Sci 70:3871-82.

75. Pluchino S, L Zanotti, E Brambilla, P Rovere-Querini, A Capobianco, C Alfaro-Cervello, G Salani, C Cossetti, G Borsellino, L Battistini, M Ponzoni, C Doglioni, JM Garcia-Verdugo, G Comi, AA Manfredi and G Martino. (2009). Immune regulatory neural stem/precursor cells protect from central nervous system autoimmunity by restraining dendritic cell function. PLoS One 4:e5959.

76. Payne NL, G Sun, C McDonald, D Layton, L Moussa, A Emerson-Webber, N Veron, C Siatskas, D Herszfeld, J Price and CC Bernard. (2013). Distinct immunomodulatory and migratory mechanisms underpin the therapeutic potential of human mesenchymal stem cells in autoimmune demyelination. Cell Transplant 22:1409-25.

77. Wyatt S, R Andres, H Rohrer and AM Davies. (1999). Regulation of neurotrophin receptor expression by retinoic acid in mouse sympathetic neuroblasts. J Neurosci 19:1062-71.

78. Pires AO, A Neves-Carvalho, N Sousa and AJ Salgado. (2014). The Secretome of Bone Marrow and Wharton Jelly Derived Mesenchymal Stem Cells Induces Differentiation and Neurite Outgrowth in SH-SY5Y Cells. Stem Cells Int 2014:438352.

79. Park H and MM Poo. (2013). Neurotrophin regulation of neural circuit development and function. Nat Rev Neurosci 14:7-23.

80. Martins LF, RO Costa, JR Pedro, P Aguiar, SC Serra, FG Teixeira, N Sousa, AJ Salgado and RD Almeida. (2017). Mesenchymal stem cells secretome-induced axonal outgrowth is mediated by BDNF. Sci Rep 7:4153.

81. Crigler L, RC Robey, A Asawachaicharn, D Gaupp and DG Phinney. (2006). Human mesenchymal stem cell subpopulations express a variety of neuro-regulatory molecules and promote neuronal cell survival and neuritogenesis. Exp Neurol 198:54-64.

82. Ribeiro CA, JS Fraga, M Graos, NM Neves, RL Reis, JM Gimble, N Sousa and AJ Salgado. (2012). The secretome of stem cells isolated from the adipose tissue and Wharton jelly acts differently on central nervous system derived cell populations. Stem Cell Res Ther 3:18.

83. Joerger-Messerli M, M Spinelli, B Oppliger, I Di Salvo, M Mueller, A Schoeberlein and DV Surbek. 394: Neuro-protective and -regenerative effects of exosomes derived from Wharton's jelly mesenchymal stem cells. American Journal of Obstetrics \& Gynecology 216:S236-S237.

84. Weiss ML, S Medicetty, AR Bledsoe, RS Rachakatla, M Choi, S Merchav, Y Luo, MS Rao, G Velagaleti and D Troyer. (2006). Human umbilical cord matrix stem cells: preliminary characterization and effect of transplantation in a rodent model of Parkinson's disease. Stem Cells 24:781-92.

85. Koh SH, KS Kim, MR Choi, KH Jung, KS Park, YG Chai, W Roh, SJ Hwang, HJ Ko, YM Huh, HT Kim and SH Kim. (2008). Implantation of human umbilical cord-derived mesenchymal stem cells as a neuroprotective therapy for ischemic stroke in rats. Brain Res 1229:233-48.

86. Lin YC, TL Ko, YH Shih, MY Lin, TW Fu, HS Hsiao, JY Hsu and YS Fu. (2011). Human umbilical mesenchymal stem cells promote recovery after ischemic stroke. Stroke 42:2045-53.

87. Yang CC, YH Shih, MH Ko, SY Hsu, H Cheng and YS Fu. (2008). Transplantation of human umbilical mesenchymal stem cells from Wharton's jelly after complete transection of the rat spinal cord. PLoS One 3:e3336.

88. Carvalho MM, FG Teixeira, RL Reis, N Sousa and AJ Salgado. (2011). Mesenchymal stem cells in the umbilical cord: phenotypic characterization, secretome and applications in central nervous system regenerative medicine. Curr Stem Cell Res Ther 6:221-8.

89. Roobrouck VD, K Vanuytsel and CM Verfaillie. (2011). Concise review: culture mediated changes in fate and/or potency of stem cells. Stem Cells 29:583-9. 
90. Roobrouck VD, C Clavel, SA Jacobs, F Ulloa-Montoya, S Crippa, A Sohni, SJ Roberts, FP Luyten, SW Van Gool, M Sampaolesi, M Delforge, A Luttun and CM Verfaillie. (2011). Differentiation potential of human postnatal mesenchymal stem cells, mesoangioblasts, and multipotent adult progenitor cells reflected in their transcriptome and partially influenced by the culture conditions. Stem Cells 29:871-82.

91. Delarosa O, W Dalemans and E Lombardo. (2012). Toll-like receptors as modulators of mesenchymal stem cells. Front Immunol 3:182.

92. Gatta V, M D'Aurora, P Lanuti, L Pierdomenico, S Sperduti, G Palka, M Gesi, M Marchisio, S Miscia and L Stuppia. (2013). Gene expression modifications in Wharton's Jelly mesenchymal stem cells promoted by prolonged in vitro culturing. BMC Genomics 14:635.

93. Klingemann H, D Matzilevich and J Marchand. (2008). Mesenchymal Stem Cells - Sources and Clinical Applications. Transfus Med Hemother 35:272-277.

94. Lee KS, JJ Nah, BC Lee, HT Lee, HS Lee, BJ So and SH Cha. (2013). Maintenance and characterization of multipotent mesenchymal stem cells isolated from canine umbilical cord matrix by collagenase digestion. Res Vet Sci 94:144-51. 


\section{Figure legends}

Figure 1: Culture characteristics of explant-derived WJ-MSC. (A) phase contrast image of an attached explant with cellular outgrowth; (B) WJ-MSC cells displaying heterogeneous morphology of fibroblast-like cells $( \pm 100 \mu \mathrm{m}$, white arrow) and small, often triangular, cells ( $\pm 20 \mu \mathrm{m}$, black arrow); (C) colony formation in dense cultures at $100 \%$ confluency (large image) and after seeding in low cell numbers at $50 \mathrm{c} / \mathrm{cm}^{2}$ for 14 days (inset: crystal violet colony stain); (D) CPD of parallel WJ-MSC cultures $(\mathrm{n}=5)$ isolated using explant culture and collagenase digestion. Culture were grown in DMEM-LG for $80 \pm 5$ days. (E) Flow cytometry analysis of MSC marker expression in explant and collagenase isolated WJ-MSC $(n=3)$ at passage 3, 5, and 7. Collagenase isolated cells showed reduced CD73 and CD90 expression with increasing passage; (F) CPD of WJ-MSC (n=10) and BM-MSC ( $\mathrm{n}=7)$ after $70 \pm 5$ days in culture. For this comparison, WJ-MSC were cultured in KODMEM/F12. Scale bars: A\&C $=200 \mu \mathrm{m} ; \mathrm{B}=100 \mu \mathrm{m}$. Data are presented as mean with $\mathrm{SD} ; * \mathrm{P}$ value $<0.05, * *$ $P$ value $<0.01$.

Figure 2: Hierarchical clustering based on differential gene expression profile of WJ-MSC, BM-MSC and MAPC. (A) Principal component analysis based on the total gene expression matrix. (B) Heatmap displaying differential gene expression patterns and clustering of the stem cell type in separate groups. Variations in expression across samples were identified with a coefficient of variance cutoff value set at 0.95 . Yellow marks high and orange-red marks low expression. Inset: Venn diagram plot showing the number of differentially regulated genes in WJ-MSC compared to both BM-MSC and MAPC.

Figure 3: BDNF secretion by WJ-MSC and BM-MSC. BDNF concentration was measured in supernatant of WJ-MSC $(\mathrm{n}=10)$ and BM-MSC $(\mathrm{n}=7)$ using sandwich ELISA. Data are shown as mean absolute concentration $(\mathrm{pg} / \mathrm{ml})$ with SD. $* * * \mathrm{P}<0.001$.

Figure 4: Neurite outgrowth of SH-SY5Y cells following exposure to CM BM-MSC and CM WJ-MSC. Control SH-SY5Y cells (A) were stimulated with RA for 5 days (B) after which RA administration was continued (C, prolonged RA exposure) or SH-SY5Y cells were either exposed to CM BM-MSC (D), CM WJMSC (E) or BDNF (F) to stimulate SH-SY5Y maturation. Quantitative analysis (G) of the mean neurite length showed that CM WJ-MSC ( $\mathrm{n}=5)$, CM BM-MSC ( $\mathrm{n}=4)$ and BDNF $(\mathrm{n}=3)$ were able to stimulate neurite outgrowth of SH-SY5Y cells after RA induction compared to control $(n=3)$, RA-induced $(n=3)$ and RA- 
maturated SH-SY5Y cells ( $\mathrm{n}=3$ ). RA maturation did not stimulate neurite outgrowth. CM WJ-MSC maturated cells had significantly longer neurites than CM BM-MSC maturated cells. No difference in mean neurite length could be observed between BDNF- and CM WJ-MSC maturated SH-SY5Y cells. Isotype control for staining specificity is presented as insert in (A). Scale bars A-F: $100 \mu \mathrm{m}$. Data are expressed as mean with SD. P values are depicted as follows: \#: $\mathrm{P}<0.001$ compared to control. $\sim: \mathrm{P}<0.001$ compared to RA induced and RA matured conditions. **: $\mathrm{P}<0.01 ; * *: \mathrm{P}<0.001$.

Figure 5: Subcutaneous stem cell transplantations exert local immune modulatory effects in Lewis rat EAE. Stem cells were subcutaneously transplanted 1 day before disease induction, and on day $3 \& 6$ after EAE induction. Leukocyte cultures derived 9 days post immunization from the popliteal lymph nodes (LN) of WJMSC, BM-MSC, and MAPC treated ( $\mathrm{n}=3$ each) and control animals $(\mathrm{n}=3)$ were restimulated with MBP. Cultures without MBP served as baseline proliferation controls (dotted red line). The stimulation index is presented as mean $\pm \mathrm{SD} .{ }^{*} \mathrm{P}<0.05$ and ${ }^{* *} \mathrm{P}<0.01$ versus restimulated cultures of saline treated animals. 


\section{$\underline{\text { Supplemental Figure legends }}$}

Figure S1: Proliferation of WJ-MSC in different culture conditions and comparison to BM-MSC. (A) Cumulative population doublings (CPD) of cells cultured in KO-DMEM/F12 (n=8) and DMEM-LG ( $\mathrm{n}=5$, culture duration: $75 \pm 8$ days). (B) Phase contrast image of collagenase isolated cells. The cultures contained large flat cells displaying stress fibers and having low replicative potential at early passage (p3-p4). Scale bar $=50$ $\mu \mathrm{m}$. (C) Flow cytometry analysis of pluripotency associated transcription factors (PPM) and (D) Agarose gel of PCR products after PPM analysis in WJ-MSC $(n=5$; donor $d 1-d 5)$ with positive control cell line NT2/D1. A description of this procedure can be found in the Supplemental materials and methods. Data are presented as mean with $\mathrm{SD} ; * \mathrm{P}$ value $<0.05$

Figure S2: Mesenchymal differentiation potential of WJ-MSC and BM-MSC. Multilineage differentiation towards adipocytes, osteoblasts and chondrocytes was validated using histochemical staining with Oil Red O (lipid droplets within the cell cytoplasm), Alizarin Red S (diffuse calcium deposits within the extracellular matrix) and Alcian Blue (glycosaminoglycan matrix within the cartilage pellet) respectively. Scale bars: adipo $=$ $50 \mu \mathrm{m}$, osteo $=100 \mu \mathrm{m}$, chondro $=200 \mu \mathrm{m}$.

Figure S3: Differential gene expression of WJ-MSC, BM-MSC and MAPC. Volcano plot showing differentially expressed genes for all three stem cell comparisons (WJ-MSC compared to BM-MSC, WJ-MSC compared to MAPC and BM-MSC compared to MAPC). Log2 fold differences are given, the red line represents a Benjamini \& Hochberg (BH)-corrected P value of 0.05 . 

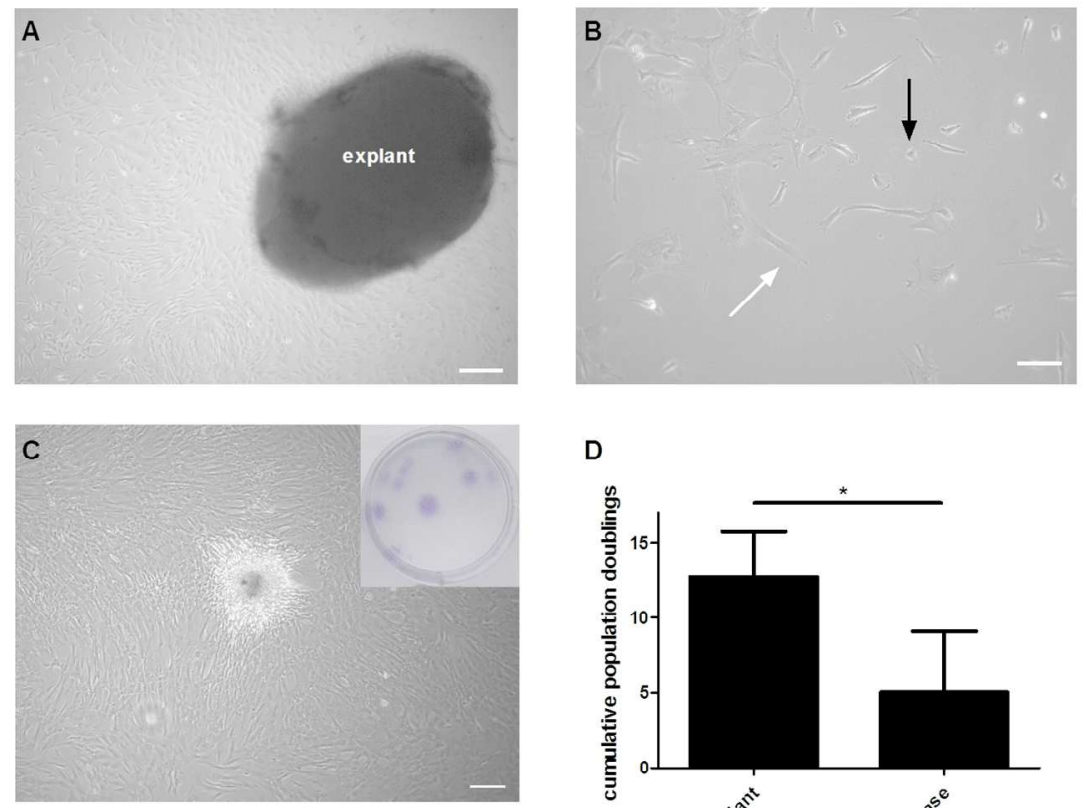

D

$E$
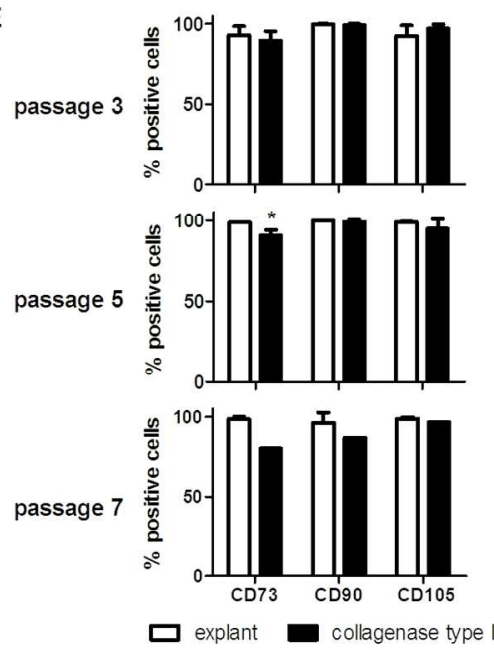

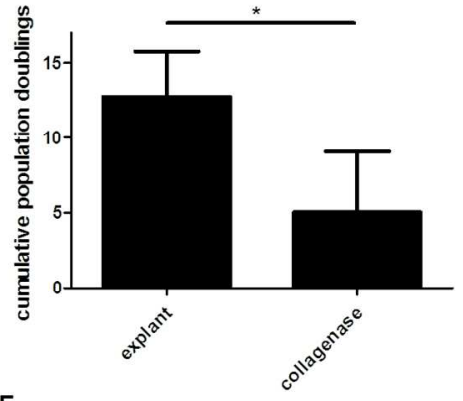

F

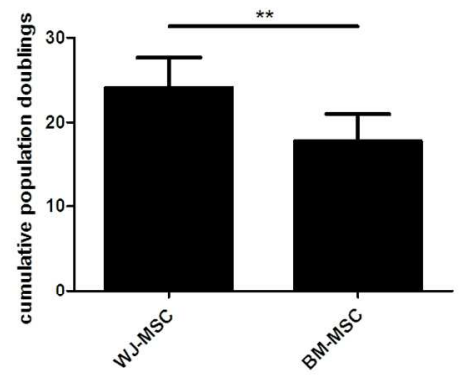

Figure 1 revised $119 \times 168 \mathrm{~mm}(300 \times 300 \mathrm{DPI})$ 
A

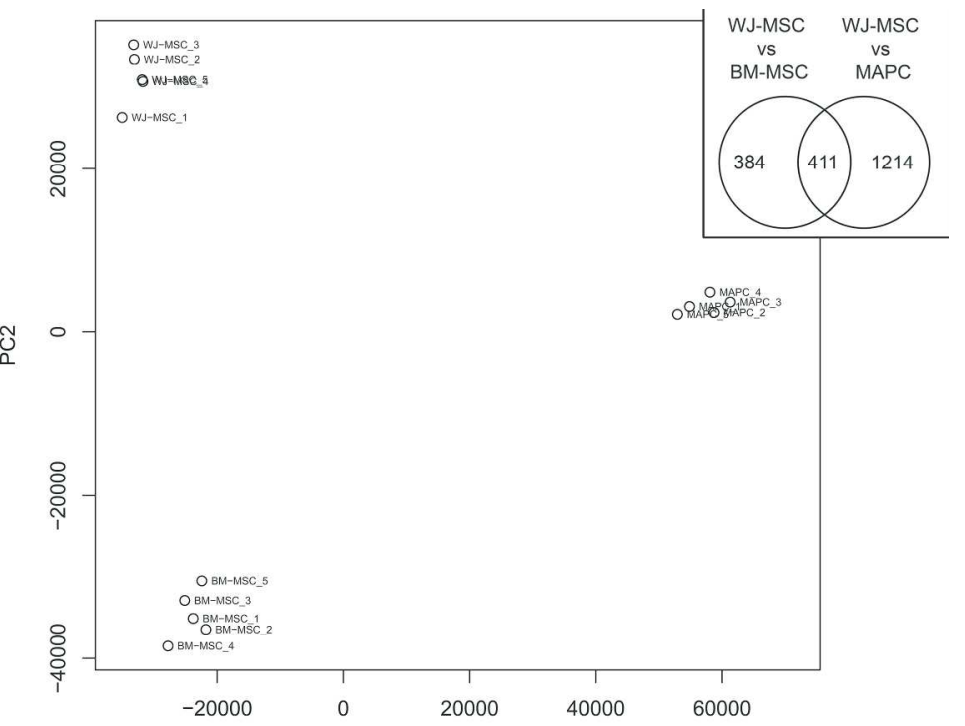

B

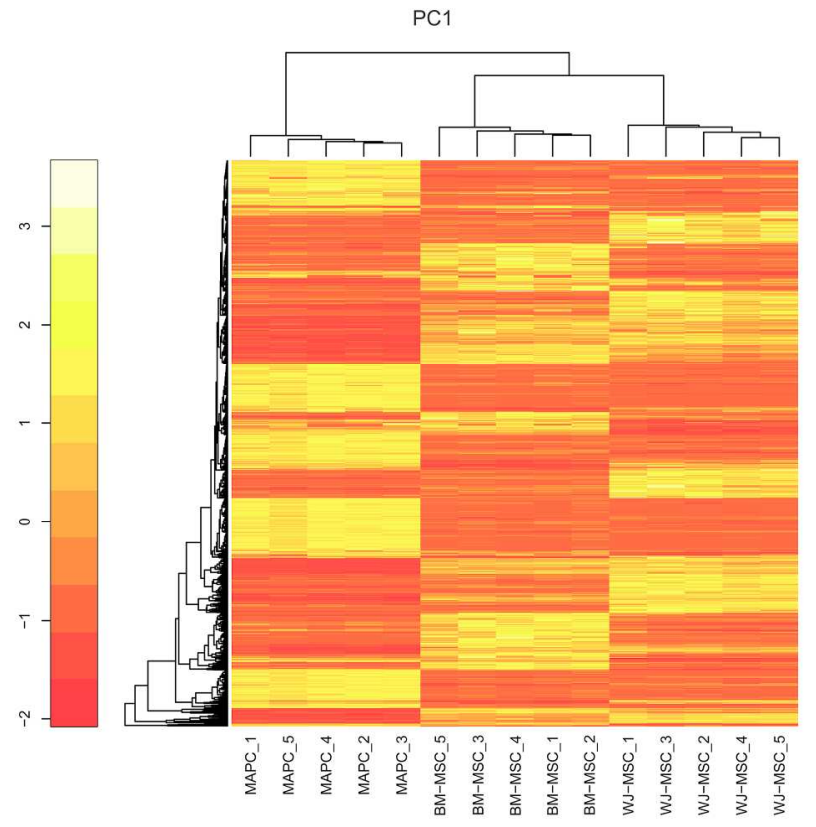

Figure 2 revised $204 \times 302 \mathrm{~mm}(300 \times 300$ DPI $)$ 


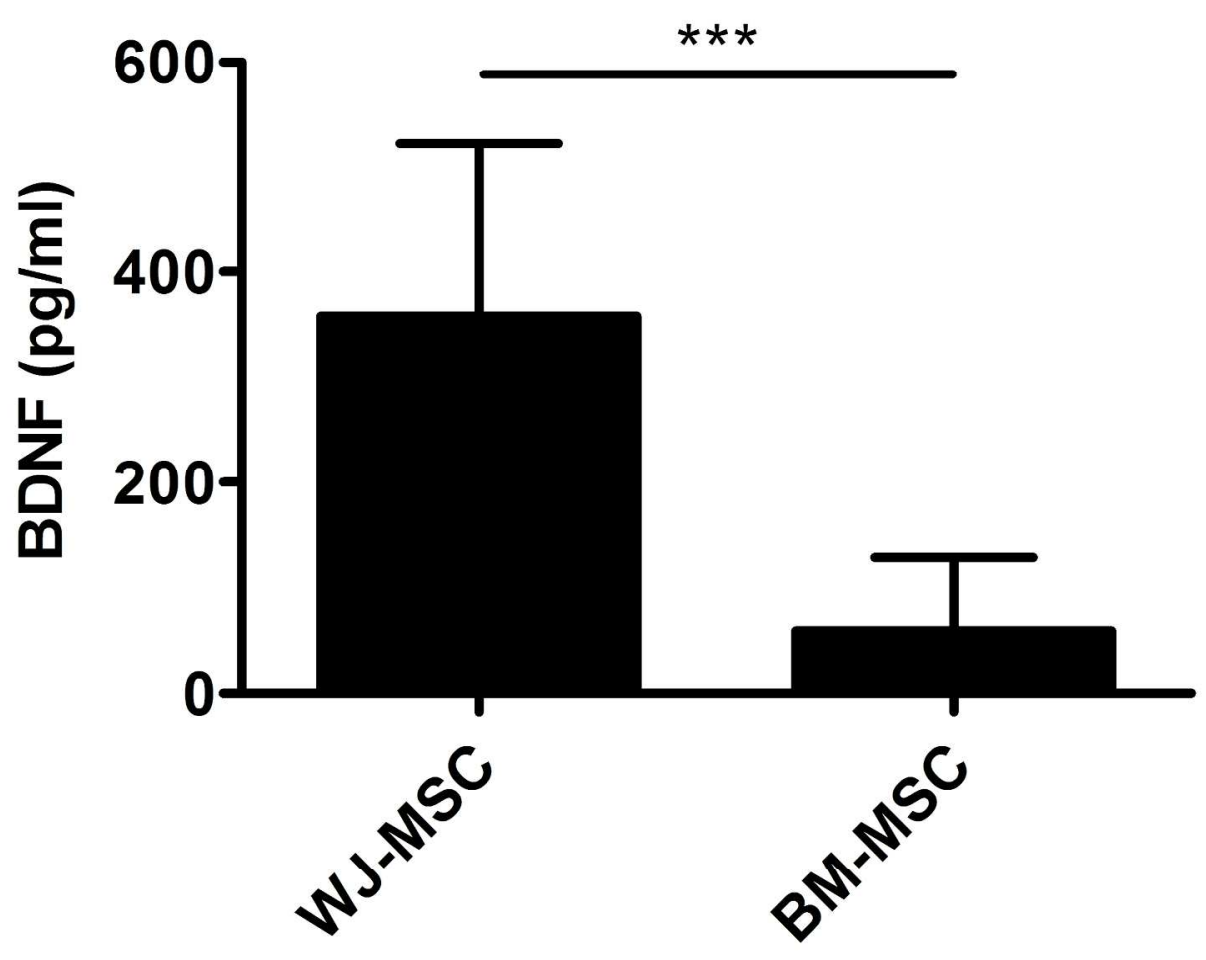

Figure 3 renamed $223 \times 182 \mathrm{~mm}(300 \times 300 \mathrm{DPI})$ 


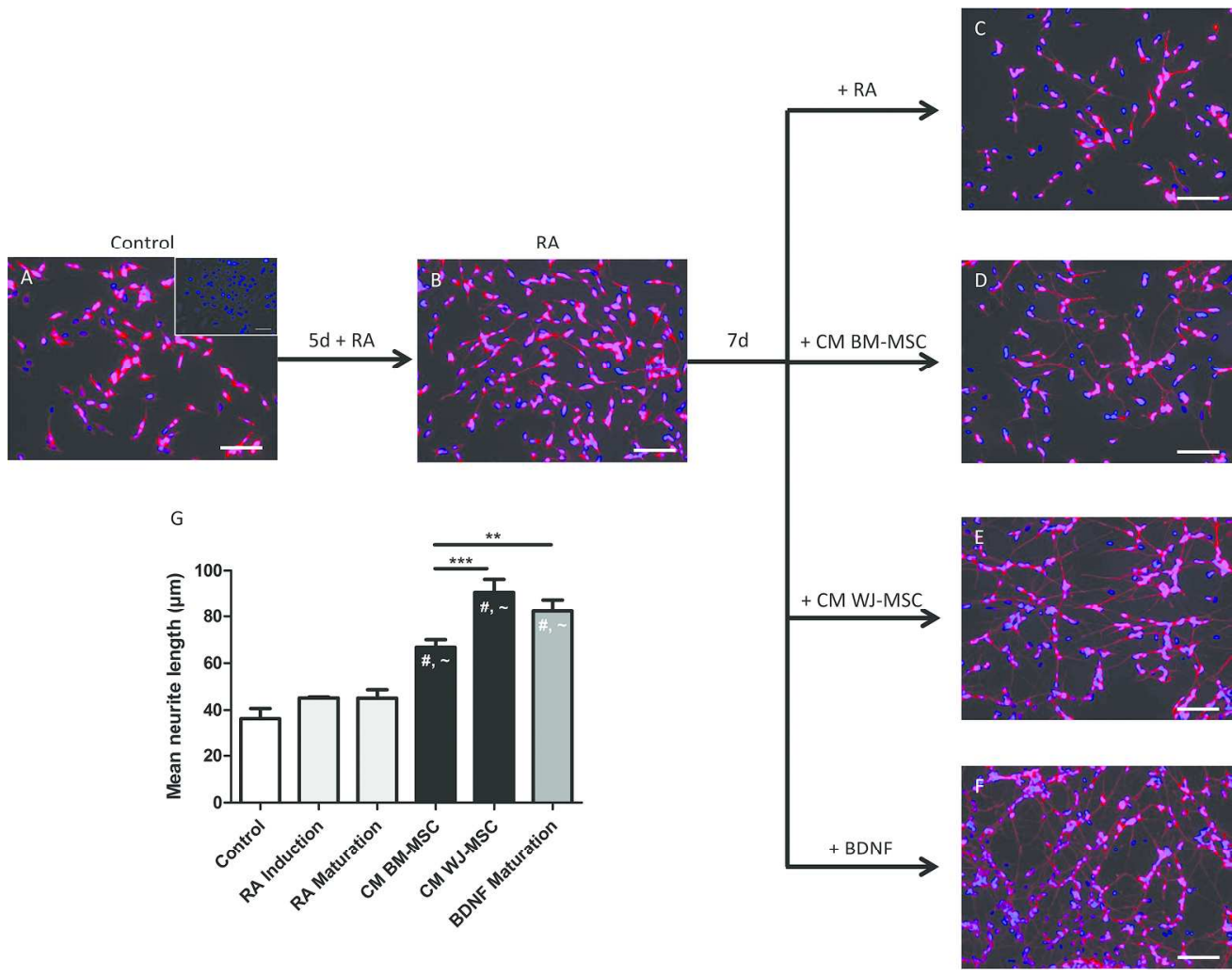

Figure 4 newly added

$196 \times 154 \mathrm{~mm}(300 \times 300 \mathrm{DPI})$ 


\section{LN}

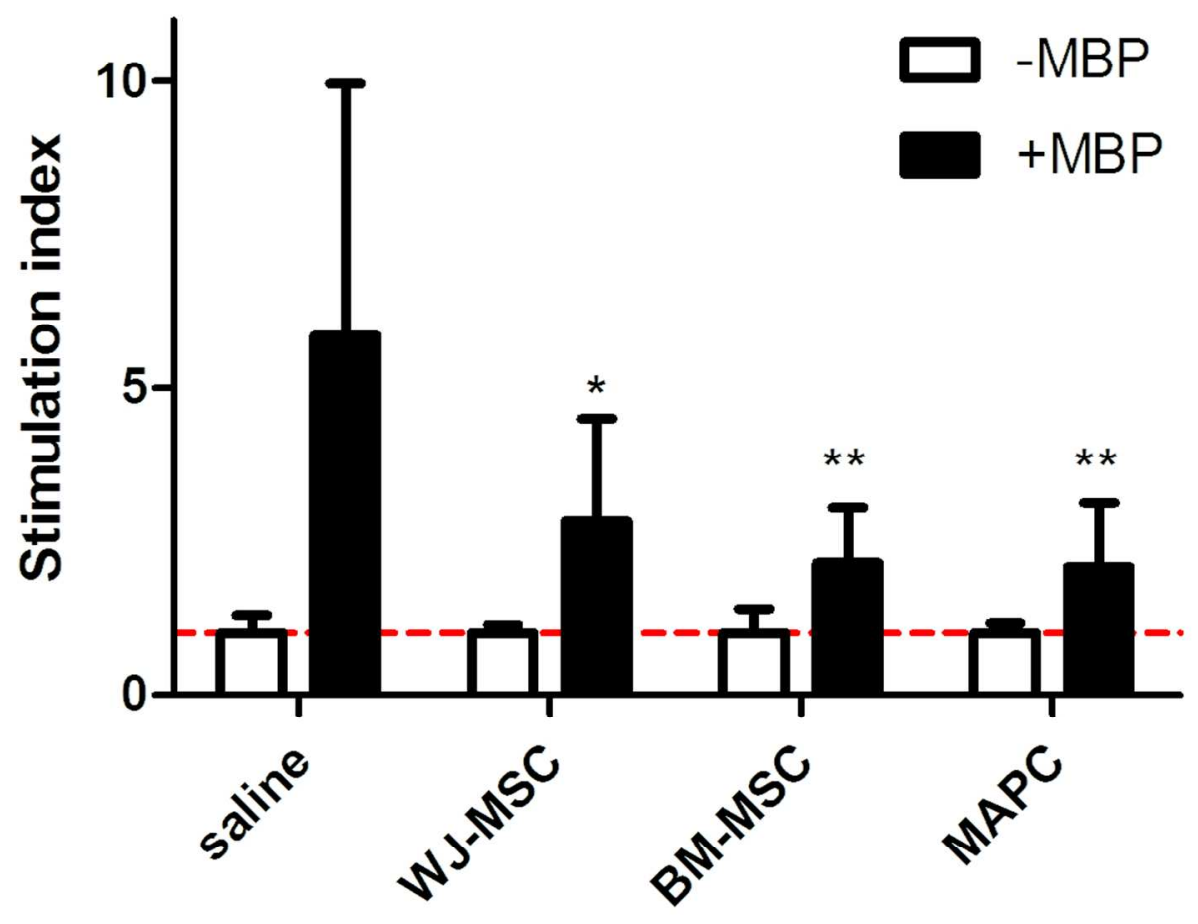

Figure 5 newly added

$98 \times 89 \mathrm{~mm}(300 \times 300$ DPI $)$ 
A
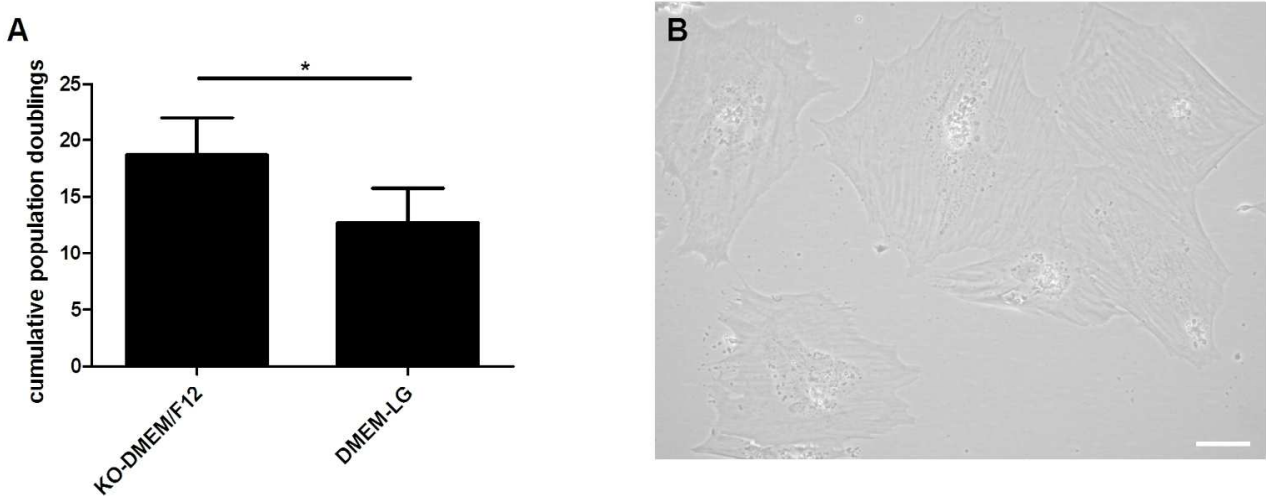

C

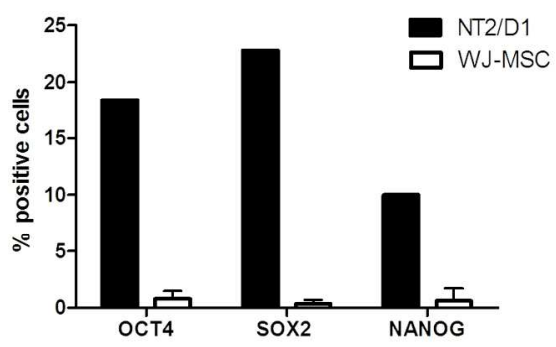

D

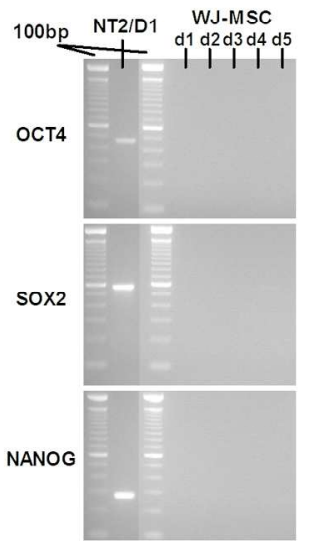

Figure S1 adapted

169x140mm (300 x 300 DPI)

37

38

39

40

41

42

43

44

45

46

47

48

49

50

51

52

53

54

55

56

57

58

59

60 


1
2
3
4
5
6
7
8
9
10
11
12
13
14
15
16
17
18
19
20
21
22
23
24
25
26
27
28
29
30
31
32
33
34
35
36
37
38
39
40
41
42
43
44
45
46
57
60
48
59
50
51
53
55
50

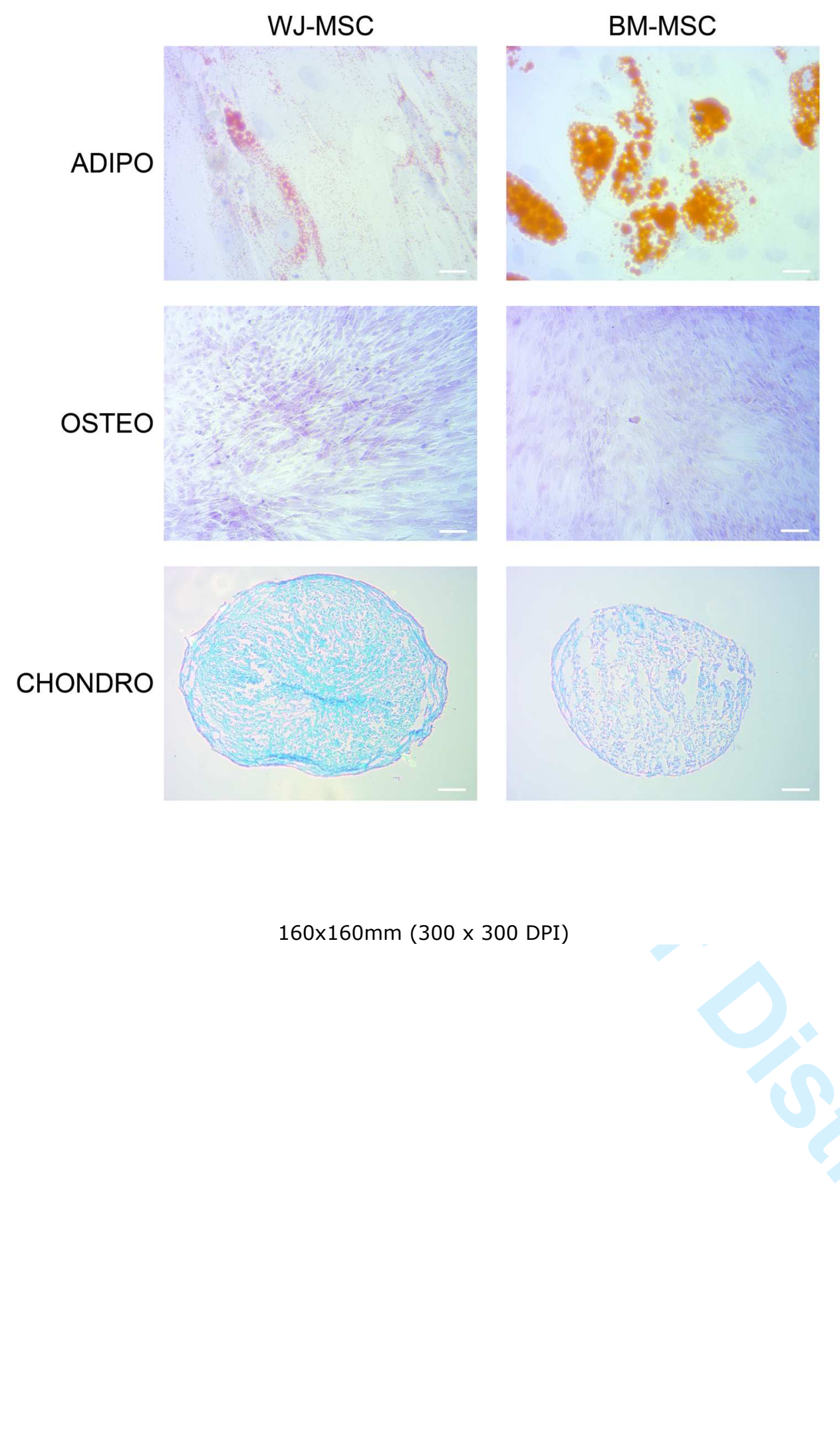

Mary Ann Liebert Inc., 140 Huguenot Street, New Rochelle, NY 10801 

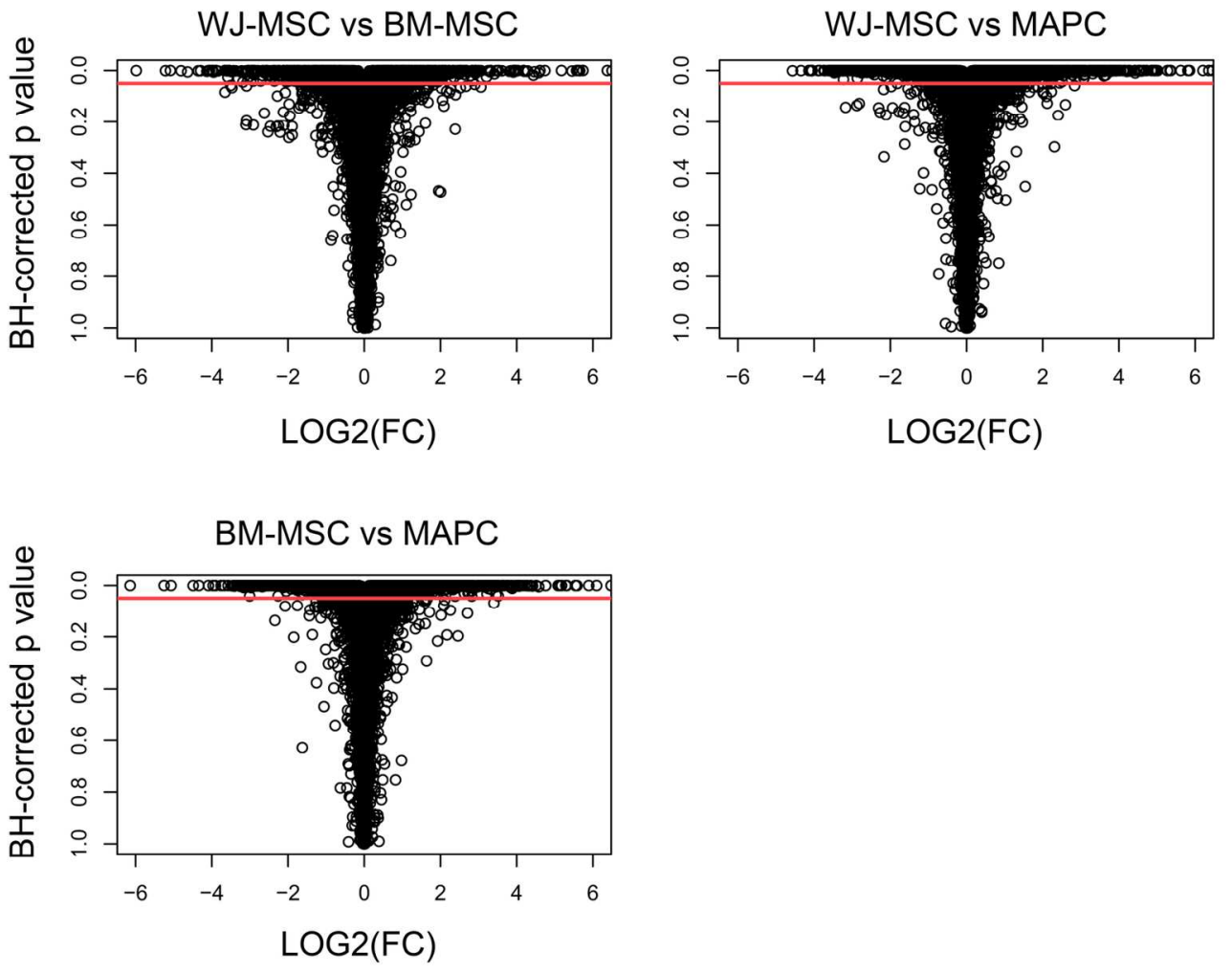

$145 \times 115 \mathrm{~mm}(300 \times 300$ DPI $)$ 
Table 1: WJ-MSC and BM-MSC surface marker expression by flow cytometry

\begin{tabular}{|c|c|c|c|c|c|}
\hline \multirow{2}{*}{ marker } & \multicolumn{2}{|c|}{$\%$ expression } & \multirow{2}{*}{ marker } & \multicolumn{2}{|c|}{$\%$ expression } \\
\hline & WJ-MSC & BM-MSC & & WJ-MSC & BM-MSC \\
\hline \multicolumn{6}{|c|}{ MSC markers } \\
\hline CD105 & $95.8 \pm 1.1$ & $96.5 \pm 0.9$ & CD10*** & $73.7 \pm 5.2$ & $25.3 \pm 6.8$ \\
\hline CD90 & $97.3 \pm 0.9$ & $96.1 \pm 1.3$ & CD13** & $58.4 \pm 4.4$ & $93.1 \pm 3$ \\
\hline CD73 & $95.9 \pm 1$ & $95.6 \pm 1.8$ & CD44 & $95.9 \pm 1$ & $98.8 \pm 0.3$ \\
\hline CD45 & $2.9 \pm 1.1$ & $4.4 \pm 4$ & CD146*** & $68.2 \pm 5.3$ & $19.3 \pm 6.9$ \\
\hline CD34 & $2.2 \pm 0.7$ & $1.4 \pm 1$ & CD117 & $7.1 \pm 2.4$ & $7 \pm 2.6$ \\
\hline CD19 & $0.9 \pm 0.2$ & $0.1 \pm 0.1$ & CD271 & $27.5 \pm 4.1$ & $24.1 \pm 7.8$ \\
\hline CD14 & $2.5 \pm 0.7$ & $2.4 \pm 1.1$ & CD133 & $1.8 \pm 0.9$ & $16.4 \pm 13.4$ \\
\hline
\end{tabular}

$\underline{\text { Adhesion molecules }}$

$\begin{array}{llllll}\text { Integrin- } \beta 1 & 96.6 \pm 1.3 & 96.9 \pm 1.1 & \text { L-selectin } & 1.8 \pm 0.5 & 1.6 \pm 0.7 \\ \text { PECAM-1 } & 0.7 \pm 0.2 & 1.1 \pm 0.4 & \text { VCAM-1 } & 17.8 \pm 4.4 & 27.5 \pm 8.8 \\ \text { Integrin- } \alpha 4 * * & 20.9 \pm 2.7 & 7.4 \pm 1.7 & \text { PSGL-1 } & 2.9 \pm 1.1 & 3.5 \pm 1.2 \\ \text { ICAM-1 } * * * & 80.2 \pm 3.6 & 12.2 \pm 3.4 & & & \end{array}$

Cytokine / Chemokine receptors

$\begin{array}{llllll}\text { IFN- } \gamma \text { R } 1 & 15.2 \pm 0.8 & 10.2 \pm 3.1 & \text { CCR2 } & 2 \pm 0.7 & 1.4 \pm 0.2 \\ \text { CXCR3 } & 15.1 \pm 3.1 & 13.9 \pm 7.1 & \text { CCR5 } & 2.1 \pm 0.6 & 1.8 \pm 0.5 \\ \text { CXCR4 } & 4.1 \pm 1.9 & 1.5 \pm 0.4 & \text { CCR7 } & 0.3 \pm 0.1 & 0.4 \pm 0.1 \\ \text { CCR1 ** } & 1.5 \pm 0.5 & 9.9 \pm 1.1 & \text { CX3CR1 } & 0.7 \pm 0.1 & 1.5 \pm 0.2\end{array}$

Immune stimulatory / inhibitory molecules

$\begin{array}{llllll}\text { TLR4* } & 34.8 \pm 9 & 71.4 \pm 7.9 & \text { PD-L1** } & 76 \pm 4.3 & 29.1 \pm 7.5 \\ \text { CD80 } & 2.8 \pm 1.3 & 1.5 \pm 0.5 & \text { PD-L2** } & 58.6 \pm 4.6 & 9.8 \pm 1.6 \\ \text { CD86 } & 7.6 \pm 1 & 6.8 \pm 1.1 & \text { HLA-ABC } & 80.4 \pm 4.9 & 78.2 \pm 7.6 \\ \text { CD40** } & 8.1 \pm 1.2 & 2.3 \pm 0.9 & \text { HLA-DR } & 2.5 \pm 1.6 & 1.4 \pm 0.8 \\ \text { CD95 } & 40.7 \pm 5.7 & 60.3 \pm 14.4 & \text { HLA-G } & 3.3 \pm 0.8 & 2.1 \pm 0.6 \\ \text { CD200* } & 88.4 \pm 4.6 & 50.9 \pm 13.4 & \text { HLA-E* } & 31.9 \pm 7.2 & 9.4 \pm 5.1\end{array}$

$* \mathrm{P}<0.05, * * \mathrm{P}<0.01, * * * \mathrm{P}<0.001$ (unpaired t-test) 
Table 2: Top 30 differentially expressed genes of WJ-MSCs compared to BM-MSC

\begin{tabular}{|c|c|c|c|c|c|c|c|c|c|}
\hline probe ID & gene name & gene symbol & $P$ value & fold change & probe ID & gene name & gene symbol & $\mathrm{P}$ value & fold change \\
\hline \multicolumn{5}{|c|}{ upregulated vs BM-MSC } & \multicolumn{5}{|c|}{ downregulated vs BM-MSC } \\
\hline 8054712 & interleukin 1, alpha & ILIA & 3.73E-04 & 90.71 & 8152522 & \multirow{4}{*}{$\begin{array}{l}\text { ectonucleotide pyrophosphatase/phosphodiesterase } 2 \\
\text { natriuretic peptide receptor C/guanylate cyclase C } \\
\text { (atrionatriuretic peptide receptor C) } \\
\text { fibronectin type III domain containing } 1 \\
\text { natriuretic peptide receptor C/guanylate cyclase C } \\
\text { (atrionatriuretic peptide receptor C) }\end{array}$} & ENPP2 & $1.66 \mathrm{E}-04$ & -50 \\
\hline 8054722 & interleukin 1 , beta & $I L 1 B$ & $2.88 \mathrm{E}-05$ & 83.16 & 8104758 & & NPR3 & $3.35 \mathrm{E}-04$ & -33.33 \\
\hline 8020779 & desmoglein 2 & $D S G 2$ & $3.24 \mathrm{E}-07$ & 53.46 & 8123104 & & FNDCl & $3.24 \mathrm{E}-07$ & -33.33 \\
\hline 8022692 & desmocollin 3 & $D S C 3$ & $2.98 \mathrm{E}-04$ & 50.43 & 8104746 & & NPR3 & $4.82 \mathrm{E}-04$ & -25 \\
\hline 8180266 & $\begin{array}{l}\text { ST6 (alpha-N-acetyl-neuraminyl-2,3-beta-galactosyl- } \\
\text { 1,3)-N-acetylgalactosaminide alpha-2,6- } \\
\text { sialyltransferase } 5\end{array}$ & ST6GALNAC5 & $8.11 \mathrm{E}-07$ & 49.42 & 8051583 & $\begin{array}{l}\text { cytochrome P450, family } 1 \text {, subfamily B, polypeptide } \\
1\end{array}$ & CYP1B1 & $2.87 \mathrm{E}-03$ & -25 \\
\hline 8005048 & \multirow{3}{*}{$\begin{array}{l}\text { myocardin } \\
\text { solute carrier family } 7 \text { (cationic amino acid } \\
\text { transporter, y+ system), member } 2 \\
\text { actin, gamma 2, smooth muscle, enteric } \\
\text { ST6 (alpha-N-acetyl-neuraminyl-2,3-beta-galactosyl- }\end{array}$} & MYOCD & 8.38E-06 & 48.37 & 7916493 & phosphatidic acid phosphatase type $2 \mathrm{~B}$ & $P P A P 2 B$ & $6.08 \mathrm{E}-04$ & -20 \\
\hline 8144786 & & SLC7A2 & 1.15E-04 & 47.57 & 7933194 & chemokine (C-X-C motif) ligand 12 & CXCL12 & $3.99 \mathrm{E}-04$ & -20 \\
\hline 8042788 & & $A C T G 2$ & $1.04 \mathrm{E}-03$ & 43.81 & 8148070 & collagen, type XIV, alpha 1 & COL14A1 & $1.54 \mathrm{E}-03$ & -16.66 \\
\hline 7902441 & $\begin{array}{l}\text { 1,3)-N-acetylgalactosaminide alpha-2,6- } \\
\text { sialyltransferase } 5\end{array}$ & ST6GALNAC5 & $8.11 \mathrm{E}-07$ & 36.13 & 8123739 & neuritin 1 & $N R N 1$ & $3.35 \mathrm{E}-04$ & -16.66 \\
\hline 7970763 & $\begin{array}{l}\text { fms-related tyrosine kinase } 1 \text { (vascular endothelial } \\
\text { growth factor/vascular permeability factor receptor) }\end{array}$ & FLT1 & $1.49 \mathrm{E}-04$ & 26.72 & 8138888 & phosphodiesterase $1 \mathrm{C}$, calmodulin-dependent $70 \mathrm{kDa}$ & $P D E 1 C$ & $8.38 \mathrm{E}-06$ & -16.66 \\
\hline 7921916 & regulator of G-protein signaling 5 & RGS5 & $1.17 \mathrm{E}-04$ & 24.44 & 8131844 & glycoprotein (transmembrane) $\mathrm{nmb}$ & $G P N M B$ & $1.05 \mathrm{E}-04$ & -16.66 \\
\hline 8100808 & $\begin{array}{l}\text { sulfotransferase family } 1 \mathrm{E} \text {, estrogen-preferring, } \\
\text { member } 1\end{array}$ & SULTIE1 & $4.48 \mathrm{E}-03$ & 23.89 & 7937039 & early B-cell factor 3 & $E B F 3$ & $1.07 \mathrm{E}-06$ & -16.66 \\
\hline 8141016 & tissue factor pathway inhibitor 2 & TFPI2 & $2.46 \mathrm{E}-03$ & 22.11 & 7920165 & filaggrin & $F L G$ & $3.28 \mathrm{E}-03$ & -16.66 \\
\hline 8161755 & aldehyde dehydrogenase 1 family, member A1 & ALDH1A1 & $9.68 \mathrm{E}-03$ & 21.68 & 8143127 & family with sequence similarity 180 , member A & FAM180A & $2.88 \mathrm{E}-05$ & -14.29 \\
\hline 8046536 & homeobox D10 & HOXD10 & $9.41 \mathrm{E}-04$ & 19.54 & 7909730 & potassium channel, subfamily $\mathrm{K}$, member 2 & KCNK2 & 8.76E-04 & -14.29 \\
\hline 7912520 & natriuretic peptide $B$ & $N P P B$ & $1.66 \mathrm{E}-03$ & 19.34 & 8115543 & early B-cell factor 1 & EBF1 & 2.99E-05 & -12.5 \\
\hline 8095680 & interleukin 8 & IL8 & $1.55 \mathrm{E}-03$ & 18.37 & 7951077 & sestrin 3 & SESN3 & $7.88 \mathrm{E}-04$ & -12.5 \\
\hline 8047788 & ADAM metallopeptidase domain 23 & $A D A M 23$ & $9.25 \mathrm{E}-04$ & 18.19 & 7924071 & $\begin{array}{l}\text { potassium voltage-gated channel, subfamily } \mathrm{H} \text { (eag- } \\
\text { related), member } 1\end{array}$ & KCNH1 & $4.58 \mathrm{E}-06$ & -12.5 \\
\hline 7963567 & keratin 8 & KRT8 & $2.88 \mathrm{E}-05$ & 18.15 & 7984813 & $\begin{array}{l}\text { immunoglobulin superfamily containing leucine-rich } \\
\text { repeat }\end{array}$ & ISLR & $7.56 \mathrm{E}-05$ & -11.11 \\
\hline 8086517 & CUB domain containing protein 1 & $C D C P 1$ & $1.90 \mathrm{E}-04$ & 16.39 & 7975779 & FBJ murine osteosarcoma viral oncogene homolog & FOS & $5.76 \mathrm{E}-04$ & -11.11 \\
\hline 8138997 & T-box 20 & $T B X 20$ & $1.01 \mathrm{E}-04$ & 15.79 & 7966122 & transmembrane protein 119 & TMEM119 & $2.28 \mathrm{E}-03$ & -11.11 \\
\hline 8092726 & claudin 1 & $C L D N 1$ & 3.61E-04 & 15.66 & 8102792 & protocadherin 18 & PCDH18 & $1.54 \mathrm{E}-03$ & -11.11 \\
\hline 8056222 & dipeptidyl-peptidase 4 & DPP4 & $1.35 \mathrm{E}-03$ & 15.59 & 8055952 & nuclear receptor subfamily 4 , group $\mathrm{A}$, member 2 & NR4A2 & 4.49E-04 & -11.11 \\
\hline 8005043 & hypothetical protein FLJ34690 & FLJ34690 & 7.45E-06 & 15.46 & 7965410 & decorin & $D C N$ & 7.91E-04 & -10 \\
\hline 8131944 & nuclear factor (erythroid-derived 2)-like 3 & $N F E 2 L 3$ & $1.90 \mathrm{E}-04$ & 15.36 & 8014063 & ecotropic viral integration site $2 \mathrm{~B}$ & EVI2B & 2.74E-03 & -9.09 \\
\hline 8025601 & intercellular adhesion molecule 1 & ICAM1 & $4.22 \mathrm{E}-04$ & 15.29 & 7919028 & T-box 15 & TBX15 & 7.99E-04 & -9.09 \\
\hline 8081657 & CD200 molecule & $C D 200$ & $3.16 \mathrm{E}-03$ & 15.07 & 8157524 & toll-like receptor 4 & TLR4 & $3.38 \mathrm{E}-03$ & -9.09 \\
\hline 7985493 & transmembrane 6 superfamily member 1 & TM6SF1 & $7.56 \mathrm{E}-05$ & 15.07 & 7919815 & cathepsin $\mathrm{K}$ & CTSK & $6.77 \mathrm{E}-04$ & -8.33 \\
\hline 8105267 & integrin, alpha 2 (CD49B, alpha 2 subunit of VLA-2) & ITGA2 & $6.59 \mathrm{E}-04$ & 14.41 & 8122099 & ectonucleotide pyrophosphatase/phosphodiesterase 1 & ENPP1 & $1.79 \mathrm{E}-03$ & -8.33 \\
\hline 7976012 & neurexin 3 & $N R X N 3$ & 5.91E-04 & 14.38 & 8150962 & $\begin{array}{l}\text { thymocyte selection-associated high mobility group } \\
\text { box }\end{array}$ & TOX & $2.90 \mathrm{E}-03$ & -8.33 \\
\hline
\end{tabular}

Mary Ann Liebert Inc., 140 Huguenot Street, New Rochelle, NY 10801 
Table 3: Top 30 differentially expressed genes of WJ-MSCs compared to MAPC

\begin{tabular}{|c|c|c|c|c|c|c|c|c|c|}
\hline probe ID & gene name & gene symbol & $\mathrm{P}$ value & fold change & probe ID & gene name & gene symbol & $\mathrm{P}$ value & fold change \\
\hline \multicolumn{5}{|c|}{ upregulated vs MAPC } & \multicolumn{5}{|c|}{ downregulated vs MAPC } \\
\hline 8146863 & sulfatase 1 & SULF1 & $6.22 \mathrm{E}-07$ & 116.57 & 8157524 & toll-like receptor 4 & TLR4 & $5.85 \mathrm{E}-04$ & -25 \\
\hline 8054712 & interleukin 1, alpha & IL1A & $9.20 \mathrm{E}-05$ & 96.39 & 8138527 & STEAP family protein MGC 87042 & MGC87042 & 2.13E-04 & -20 \\
\hline 8042788 & actin, gamma 2 , smooth muscle, enteric & ACTG2 & $2.02 \mathrm{E}-05$ & 87.83 & 8095744 & amphiregulin & $A R E G$ & $1.50 \mathrm{E}-05$ & -16.66 \\
\hline 8054722 & interleukin 1 , beta & ILIB & 3.19E-06 & 82.09 & 8143127 & family with sequence similarity 180 , member A & FAM180A & $2.01 \mathrm{E}-05$ & -16.66 \\
\hline 8081657 & CD200 molecule & $C D 200$ & 2.03E-06 & 73.72 & 7916493 & phosphatidic acid phosphatase type $2 \mathrm{~B}$ & $P P A P 2 B$ & 4.03E-04 & -16.66 \\
\hline 8005048 & myocardin & $M Y O C D$ & 8.99E-07 & 57.73 & 8150962 & $\begin{array}{l}\text { thymocyte selection-associated high mobility group } \\
\text { box }\end{array}$ & TOX & 4.95E-05 & -16.66 \\
\hline 8020779 & desmoglein 2 & $D S G 2$ & $1.40 \mathrm{E}-06$ & 56.04 & 8059580 & delta/notch-like EGF repeat containing & DNER & 9.81E-05 & -14.29 \\
\hline 8022692 & desmocollin 3 & DSC3 & $8.22 \mathrm{E}-05$ & 49.25 & 8149955 & PDZ binding kinase & $P B K$ & $9.35 \mathrm{E}-06$ & -14.29 \\
\hline 8006433 & $\begin{array}{l}\text { chemokine (C-C motif) ligand } 2 \\
\text { ST6 (alpha-N-acetyl-neuraminyl-2,3-beta-galactosyl- }\end{array}$ & $C C L 2$ & 2.03E-06 & 41.05 & 7989647 & KIAA0101 & KIAA0101 & 4.13E-06 & -14.29 \\
\hline 8180266 & $\begin{array}{l}\text { 1,3)-N-acetylgalactosaminide alpha-2,6- } \\
\text { sialyltransferase } 5\end{array}$ & ST6GALNAC5 & 1.84E-07 & 40.47 & 7914878 & claspin & $C L S P N$ & $1.39 \mathrm{E}-05$ & -14.29 \\
\hline 7922976 & $\begin{array}{l}\text { prostaglandin-endoperoxide synthase } 2 \\
\text { (prostaglandin G/H synthase and cyclooxygenase) }\end{array}$ & $P T G S 2$ & $1.16 \mathrm{E}-04$ & 38.64 & 8001133 & SHC SH2-domain binding protein 1 & $S H C B P 1$ & 2.07E-04 & -12.5 \\
\hline 7921916 & regulator of G-protein signaling 5 & RGS5 & $1.72 \mathrm{E}-04$ & 32.31 & 7896709 & & & 1.43E-04 & -12.5 \\
\hline 8136200 & carboxypeptidase A4 & CPA4 & $1.45 \mathrm{E}-05$ & 31.33 & 8161964 & FERM domain containing 3 & FRMD3 & $1.10 \mathrm{E}-04$ & -12.5 \\
\hline 8056222 & dipeptidyl-peptidase 4 & DPP4 & 3.64E-05 & 30.65 & 7906930 & $\begin{array}{l}\text { NUF2, NDC } 80 \text { kinetochore complex component, } \\
\text { homolog (S. cerevisiae) }\end{array}$ & $N U F 2$ & 7.19E-05 & -12.5 \\
\hline 7902441 & $\begin{array}{l}\text { ST6 (alpha-N-acetyl-neuraminyl-2,3-beta-galactosyl- } \\
\text { 1,3)-N-acetylgalactosaminide alpha-2,6- } \\
\text { sialyltransferase } 5\end{array}$ & ST6GALNAC5 & 2.29E-07 & 30.55 & 7970513 & spindle and kinetochore associated complex subunit 3 & SKA3 & $5.22 \mathrm{E}-06$ & -12.5 \\
\hline 8092726 & claudin 1 & CLDN1 & 2.19E-04 & 30.49 & 7974404 & cyclin-dependent kinase inhibitor 3 & $C D K N 3$ & 2.07E-04 & -12.5 \\
\hline 8157487 & pregnancy-associated plasma protein A, pappalysin 1 & $P A P P A$ & $6.78 \mathrm{E}-06$ & 29.82 & 8077899 & peroxisome proliferator-activated receptor gamma & $P P A R G$ & $8.39 \mathrm{E}-06$ & -12.5 \\
\hline 8047788 & ADAM metallopeptidase domain 23 & ADAM23 & $1.45 \mathrm{E}-06$ & 28.84 & 7978846 & polymerase (DNA directed), epsilon 2 ( $\mathrm{p} 59$ subunit) & POLE2 & $5.72 \mathrm{E}-05$ & -11.11 \\
\hline 7976012 & neurexin 3 & $N R X N 3$ & $5.94 \mathrm{E}-06$ & 26.39 & 7982757 & cancer susceptibility candidate 5 & CASC5 & 2.61E-04 & -11.11 \\
\hline 8136248 & mesoderm specific transcript homolog (mouse) & MEST & 7.18E-05 & 25.05 & 8157650 & $\begin{array}{l}\text { prostaglandin-endoperoxide synthase } 1 \\
\text { (prostaglandin G/H synthase and cyclooxygenase) }\end{array}$ & PTGS1 & $6.84 \mathrm{E}-06$ & -11.11 \\
\hline 8131803 & interleukin 6 (interferon, beta 2) & IL6 & $9.59 \mathrm{E}-04$ & 24.14 & 8117594 & histone cluster $1, \mathrm{H} 2 \mathrm{bm}$ & HIST1H2BM & $5.52 \mathrm{E}-06$ & -11.11 \\
\hline 8025601 & intercellular adhesion molecule 1 & ICAM1 & $7.22 \mathrm{E}-07$ & 23.65 & 8124394 & histone cluster $1, \mathrm{H} 2 \mathrm{bb}$ & HIST1H2BB & $1.07 \mathrm{E}-05$ & -11.11 \\
\hline 7970763 & $\begin{array}{l}\text { fms-related tyrosine kinase } 1 \text { (vascular endothelial } \\
\text { growth factor/vascular permeability factor receptor) }\end{array}$ & FLTI & 4.42E-06 & 23.52 & 7962058 & $\begin{array}{l}\text { transmembrane and tetratricopeptide repeat } \\
\text { containing } 1\end{array}$ & TMTC1 & $1.83 \mathrm{E}-03$ & -11.11 \\
\hline 7960919 & microfibrillar associated protein 5 & MFAP5 & $9.35 \mathrm{E}-06$ & 23.45 & 8097356 & polo-like kinase 4 & PLK4 & $1.56 \mathrm{E}-04$ & -11.11 \\
\hline 8121838 & tumor protein D52-like 1 & TPD52L1 & $1.69 \mathrm{E}-06$ & 22.94 & 7916898 & DEP domain containing 1 & $D E P D C 1$ & $4.55 \mathrm{E}-05$ & -11.11 \\
\hline 7965403 & lumican & LUM & $2.16 \mathrm{E}-04$ & 22.93 & 7940147 & family with sequence similarity 111 , member B & FAM111B & $1.14 \mathrm{E}-05$ & -11.11 \\
\hline 8161755 & aldehyde dehydrogenase 1 family, member A1 & $A L D H 1 A 1$ & $5.21 \mathrm{E}-03$ & 21.49 & 7927710 & cyclin-dependent kinase 1 & CDK1 & $3.22 \mathrm{E}-04$ & -11.11 \\
\hline 8102532 & phosphodiesterase $5 \mathrm{~A}$, cGMP-specific & PDE5A & $2.47 \mathrm{E}-06$ & 21.37 & 8097628 & hedgehog interacting protein & HHIP & 4.89E-03 & -11.11 \\
\hline 8123246 & $\begin{array}{l}\text { solute carrier family } 22 \text { (extraneuronal monoamine } \\
\text { transporter), member } 3\end{array}$ & $S L C 22 A 3$ & $5.88 \mathrm{E}-05$ & 19.43 & 7960340 & forkhead box M1 & FOXMI & 7.31E-05 & -11.11 \\
\hline 8046536 & homeobox D10 & HOXD10 & $1.12 \mathrm{E}-03$ & 19.25 & 8151871 & cyclin E2 & CCNE2 & 2.03E-06 & -11.11 \\
\hline
\end{tabular}


Table 4: Microarray comparison of different effector molecule categories in WJ-MSC versus BM-MSC and MAPC

\begin{tabular}{|c|c|c|c|}
\hline Gene description & Gene symbol & $\begin{array}{c}\mathrm{FC} \\
\mathrm{WJ} / \mathrm{BM} \\
\end{array}$ & $\begin{array}{c}\text { FC } \\
\text { WJ/MAPC }\end{array}$ \\
\hline \multicolumn{4}{|l|}{ Adhesion molecules and receptors } \\
\hline intercellular adhesion molecule 1 & ICAMI & 15.29 & 23.65 \\
\hline toll-like receptor 4 & $T L R 4$ & -9.09 & -25 \\
\hline vascular cell adhesion molecule 1 & VCAMI & -4.22 & 5.68 \\
\hline major histocompatibility complex, class I & $H L A-A B C$ & 1.36 & 4.36 \\
\hline major histocompatibility complex, class I, G & $H L A-G$ & 1.23 & 3.73 \\
\hline major histocompatibility complex, class I, E & $H L A-E$ & 1.34 & 2.86 \\
\hline major histocompatibility complex, class I, F & $H L A-F$ & 1.34 & 2.93 \\
\hline desmoglein 2 & $D S G 2$ & 53.46 & 56.04 \\
\hline desmocollin 3 & DSC3 & 50.43 & 49.25 \\
\hline lumican & $L U M$ & -2.58 & 22.93 \\
\hline \multicolumn{4}{|l|}{ Immune modulatory molecules } \\
\hline CD200 molecule & $C D 200$ & 15.07 & 73.72 \\
\hline prostaglandin E synthase & PTGES & -4.40 & 1.58 \\
\hline $\begin{array}{l}\text { prostaglandin-endoperoxide synthase } 1 \text { (prostaglandin } \mathrm{G} / \mathrm{H} \\
\text { synthase and cyclooxygenase) }\end{array}$ & COX-1 & 1.1 & -11.11 \\
\hline $\begin{array}{l}\text { prostaglandin-endoperoxide synthase } 2 \text { (prostaglandin } \mathrm{G} / \mathrm{H} \\
\text { synthase and cyclooxygenase) }\end{array}$ & $C O X-2$ & 1.98 & 38.64 \\
\hline integrin, alpha 2 (CD49B, alpha 2 subunit of VLA-2 receptor) & $C D 49 B$ & 14.40 & 4.65 \\
\hline hepatocyte growth factor (hepapoietin A; scatter factor) & $H G F$ & -2.15 & 1.22 \\
\hline Programmed death-ligand 1 (CD274 / B7-H1) & $P D-L 1$ & 11.25 & 1.89 \\
\hline Indoleamine 2,3-Dioxygenase 1 & $I D O-1$ & n.d. & n.d. \\
\hline \multicolumn{4}{|l|}{ Cytokines and chemokines } \\
\hline Interleukin 1 , beta & $I L 1 B$ & 83.16 & 82.09 \\
\hline Interleukin 6 & IL6 & 1.11 & 24.14 \\
\hline Interleukin 8 & IL8 & 18.37 & 6.29 \\
\hline chemokine (C-C motif) ligand 2 & $C C L 2$ & 3.07 & 41.05 \\
\hline chemokine (C-X-C motif) ligand 2 & CXCL2 & 2.21 & 1.14 \\
\hline chemokine (C-X-C motif) ligand 12 & CXCL12 & -20 & -1.11 \\
\hline \multicolumn{4}{|l|}{ Growth factors } \\
\hline brain-derived neurotrophic factor & $B D N F$ & 2.99 & 5.15 \\
\hline leukemia inhibitory factor & LIF & 2.41 & 5.82 \\
\hline neurotrophin 3 & $N T F 3$ & 3.17 & 3.87 \\
\hline transforming growth factor, beta 2 & $T G F B 2$ & 3.57 & 7.68 \\
\hline vascular endothelial growth factor $\mathrm{A}$ & $V E G F A$ & 1.13 & 5.08 \\
\hline fibroblast growth factor 2 (basic) & $F G F 2$ & 1.83 & 2.37 \\
\hline insulin-like growth factor 1 (somatomedin $\mathrm{C}$ ) & $I G F 1$ & -1.56 & 1.08 \\
\hline glial cell derived neurotrophic factor & $G D N F$ & 1.36 & 1.05 \\
\hline \multicolumn{4}{|l|}{ Enzymes and signaling molecules } \\
\hline sulfatase 1 & SULF1 & 1.31 & 116.57 \\
\hline aldehyde dehydrogenase 1 family, member A1 & $A L D H I A 1$ & 21.68 & 21.49 \\
\hline SMAD family member 3 & SMAD3 & 2.13 & 4.40 \\
\hline POU class 5 homeobox 1 pseudogene 3 & OCT4 & -1.12 & 1.02 \\
\hline SRY (sex determining region Y)-box 2 & SOX2 & n.d. & n.d. \\
\hline Nanog homeobox & NANOG & 1.10 & 1.08 \\
\hline
\end{tabular}

$\overline{\mathrm{FC}}=$ fold change; n.d. $=$ not detectable 
Table 5: Canonical pathways and functions in the WJ-MSC gene pool $(n=411$ genes $)$ differentially regulated to both BM-MSC and MAPC (IPA)

\begin{tabular}{lll}
\hline category & P value * & \# molecules \\
\hline Canonical pathways & & \\
HMGB1 Signaling & $1.26 \mathrm{E}-05$ & $12 / 118$ \\
Hepatic Fibrosis / Hepatic Stellate Cell Activation & $1.33 \mathrm{E}-05$ & $15 / 181$ \\
Caveolar-mediated Endocytosis Signaling & $1.87 \mathrm{E}-05$ & $9 / 68$ \\
Agranulocyte Adhesion and Diapedesis & $1.01 \mathrm{E}-04$ & $13 / 168$ \\
Granulocyte Adhesion and Diapedesis & $2.20 \mathrm{E}-04$ & $12 / 158$ \\
Molecular and cellular functions & & \\
Cellular Development & $5.97 \mathrm{E}-05-5.33 \mathrm{E}-18$ & 201 \\
Cellular Movement & $6.01 \mathrm{E}-05-7.89 \mathrm{E}-18$ & 139 \\
Cellular Growth and Proliferation & $5.97 \mathrm{E}-05-2.02 \mathrm{E}-17$ & 213 \\
Cell Morphology & $5.39 \mathrm{E}-05-4.10 \mathrm{E}-15$ & 132 \\
Cell Death and Survival & $5.38 \mathrm{E}-05-9.86 \mathrm{E}-15$ & 174 \\
Physiological system development and function & & \\
Embryonic Development & $6.01 \mathrm{E}-05-3.80 \mathrm{E}-17$ & 138 \\
Organismal Development & $5.58 \mathrm{E}-05$ - 3.80E-17 & 189 \\
Organismal Survival & $3.05 \mathrm{E}-05$ - 1.34E-15 & 147 \\
Tissue Morphology & $4.88 \mathrm{E}-05$ - 4.11E-15 & 146 \\
Cardiovascular System Development and Function & $5.58 \mathrm{E}-05-1.05 \mathrm{E}-14$ & 133 \\
\hline
\end{tabular}

$\mathrm{P}$ value* $=$ for molecular and cellular functions and physiological system development and function a range is given as the categories are comprised of multiple sub functions 


\section{Supplemental tables}

Table S1: Antibodies for flow cytometry analysis

\begin{tabular}{|c|c|c|c|c|}
\hline Marker & Clone & Isotype & Label & Company \\
\hline CD10 & CB-CALLA & mIgG2b & $\mathrm{PE}$ & eBioscience \\
\hline CD13 & WM-15 & $\operatorname{mIgG} 1 \kappa$ & FITC & eBioscience \\
\hline CD14 & MEM-15 & mIgG1 & $\mathrm{PE}$ & Immunotools \\
\hline CD19 & LT19 & mIgG1 & FITC & Immunotools \\
\hline Integrin- $\beta 1$ & TS2/16 & mIgG1 & FITC & eBioscience \\
\hline PECAM-1 & MEM-05 & mIgG1 & FITC & Immunotools \\
\hline CD34 & $4 \mathrm{H} 11$ & mIgG1 & $\mathrm{PE}$ & Immunotools \\
\hline CD40 & $5 \mathrm{C} 3$ & $\operatorname{mIgG1\kappa }$ & FITC & eBioscience \\
\hline CD44 & IM7 & $\mathrm{rIgG} 2 \mathrm{~b} \kappa$ & FITC & eBioscience \\
\hline CD45 & MEM-28 & mIgG1 & FITC & Immunotools \\
\hline Integrin- $\alpha 4$ & BU49 & mIgG1 & FITC & Immunotools \\
\hline ICAM-1 & HA58 & $\operatorname{mIgG1\kappa }$ & $\mathrm{PE}$ & eBioscience \\
\hline L-selectin & DREG-56 & $\operatorname{mIgG} 1 \kappa$ & FITC & BD Biosciences \\
\hline CD73 & AD2 & mIgG1к & $\mathrm{PE}$ & BD Biosciences \\
\hline CD80 & L307.4 & $\operatorname{mIgG1\kappa }$ & $\mathrm{PE}$ & BD Biosciences \\
\hline CD86 & 2331(FUN-1) & $\operatorname{mIgG} 1 \kappa$ & FITC & BD Biosciences \\
\hline CD90 & $5 \mathrm{E} 10$ & $\operatorname{mIgG1\kappa }$ & FITC & eBioscience \\
\hline CD95 & $\mathrm{DX} 2$ & $\operatorname{mIgG} 1 \kappa$ & FITC & BD Biosciences \\
\hline CD105 & SN6 & mIgG1 & $\mathrm{PE}$ & eBioscience \\
\hline VCAM-1 & STA & $\operatorname{mIgG} 1 \kappa$ & $\mathrm{PE}$ & eBioscience \\
\hline CD117 & YB5.B8 & $\operatorname{mIgG1\kappa }$ & $\mathrm{PE}$ & eBioscience \\
\hline IFN- $\gamma \mathrm{R} 1$ & GIR-208 & mIgG1 & PE & eBioscience \\
\hline CD133 & AC133 & mIgG1 & PE & Miltenyi Biotec \\
\hline CD146 & P1H12 & $\operatorname{mIgG} 1 \kappa$ & PE & BD Biosciences \\
\hline PSGL-1 & KPL-1 & $\operatorname{mIgG1\kappa }$ & $\mathrm{PE}$ & BD Biosciences \\
\hline CXCR3 & $1 \mathrm{C} 6$ & $\operatorname{mIgG1\kappa }$ & $\mathrm{PE}$ & BD Biosciences \\
\hline CXCR4 & $12 \mathrm{G} 5$ & $\operatorname{mIgG} 2 \mathrm{a} \kappa$ & $\mathrm{PE}$ & BD Biosciences \\
\hline CCR1 & 53504 & $\mathrm{mIgG} 2 \mathrm{~b}$ & $\mathrm{PE}$ & R\&D Systems \\
\hline CCR2 & 48607 & $\operatorname{mIgG} 2 b$ & PerCP & R\&D Systems \\
\hline CCR5 & $\mathrm{R} 22 / 7$ & $\operatorname{mIgG} 1 \kappa$ & PE & eBioscience \\
\hline CCR7 & 3D12 & $\mathrm{rIgG} 2 \mathrm{a} \kappa$ & $\mathrm{PE}$ & eBioscience \\
\hline CD200 & OX104 & $\operatorname{mIgG} 1 \kappa$ & $\mathrm{PE}$ & eBioscience \\
\hline CD271 & ME20.4 & $\operatorname{mIgG} 1 \kappa$ & FITC & Biolegend \\
\hline CX3CR1 & 2A9-1 & $\operatorname{rIgG} 2 \mathrm{a} \kappa$ & $\mathrm{PE}$ & MBL International \\
\hline HLA-ABC & W6/32 & mIgG2a & FITC & Immunotools \\
\hline HLA-DR & MEM-12 & $\operatorname{mIgG} 1 \kappa$ & $\mathrm{PE}$ & Immunotools \\
\hline HLA-E & $3 \mathrm{D} 12$ & mIgG1 & $\mathrm{PE}$ & eBioscience \\
\hline HLA-G & $87 \mathrm{G}$ & $\operatorname{mIgG} 2 \mathrm{a}$ & $\mathrm{PE}$ & eBioscience \\
\hline NANOG & $\mathrm{N} 31-355$ & $\operatorname{mIgG} 1 \kappa$ & $\mathrm{PE}$ & BD Biosciences \\
\hline OCT3/4 & $40 /$ Oct-3 & $\operatorname{mIgG1\kappa }$ & PerCP-Cy5.5 & BD Biosciences \\
\hline PD-L1 & MIH1 & mIgG1 & $\mathrm{PE}$ & eBioscience \\
\hline PD-L2 & MIH18 & $\operatorname{mIgG} 1 \kappa$ & $\mathrm{PE}$ & eBioscience \\
\hline SOX2 & 245610 & $\mathrm{mIgG} 2 \mathrm{a \kappa}$ & Alexa Fluor ${ }^{\circledR} 647$ & BD Biosciences \\
\hline TLR4 & HTA125 & $\operatorname{mIgG} 2 \mathrm{a} \kappa$ & $\mathrm{PE}$ & eBioscience \\
\hline
\end{tabular}

For isotype: $\mathrm{m}=$ mouse; $\mathrm{r}=$ rat 
Table S2: Overrepresented KEGG pathways and biological functions within the WJ-MSC gene pool ( $\mathrm{n}=411$ genes) differentially regulated to both BM-MSC and MAPC (DAVID)

\begin{tabular}{|c|c|c|c|}
\hline Category & Term & P-value & Benjamini \\
\hline \multirow[t]{11}{*}{ KEGG } & arrhythmogenic right ventricular cardiomyopathy & $4,50 \mathrm{E}-06$ & $5,10 \mathrm{E}-04$ \\
\hline & ECM-receptor interaction & $8,90 \mathrm{E}-05$ & $5,00 \mathrm{E}-03$ \\
\hline & focal adhesion & $1,00 \mathrm{E}-03$ & $3,70 \mathrm{E}-02$ \\
\hline & o-glycan biosynthesis & $1,20 \mathrm{E}-03$ & $3,40 \mathrm{E}-02$ \\
\hline & hypertrophic cardiomyopathy & $1,90 \mathrm{E}-03$ & 4,20E-02 \\
\hline & hematopoietic cell lineage & $2,20 \mathrm{E}-03$ & $4,10 \mathrm{E}-02$ \\
\hline & MAPK signaling pathway & $2,40 \mathrm{E}-03$ & $3,80 \mathrm{E}-02$ \\
\hline & dilated cardiomyopathy & $3,20 \mathrm{E}-03$ & $4,40 \mathrm{E}-02$ \\
\hline & complement and coagulation cascades & $1,10 \mathrm{E}-02$ & $1,30 \mathrm{E}-01$ \\
\hline & cell adhesion molecules & $2,50 \mathrm{E}-02$ & $2,50 \mathrm{E}-01$ \\
\hline & apoptosis & $3,20 \mathrm{E}-02$ & $2,90 \mathrm{E}-01$ \\
\hline \multicolumn{4}{|c|}{ GOTERM_BP } \\
\hline & cell adhesion & $1,40 \mathrm{E}-07$ & $3,10 \mathrm{E}-04$ \\
\hline & biological adhesion & $1,50 \mathrm{E}-07$ & $1,60 \mathrm{E}-04$ \\
\hline & regulation of cell proliferation & $3,00 \mathrm{E}-06$ & $1,10 \mathrm{E}-03$ \\
\hline & positive regulation of macromolecule metabolic process & $2,20 \mathrm{E}-04$ & $1,60 \mathrm{E}-02$ \\
\hline & positive regulation of biosynthetic process & $1,70 \mathrm{E}-05$ & $3,50 \mathrm{E}-03$ \\
\hline & positive regulation of cellular biosynthetic process & $3,10 \mathrm{E}-05$ & $4,30 \mathrm{E}-03$ \\
\hline & regulation of apoptosis & $6,60 \mathrm{E}-04$ & $3,40 \mathrm{E}-02$ \\
\hline & regulation of programmed cell death & $7,80 \mathrm{E}-04$ & $3,70 \mathrm{E}-02$ \\
\hline & regulation of cell death & $8,30 \mathrm{E}-04$ & $3,60 \mathrm{E}-02$ \\
\hline & positive regulation of macromolecule biosynthetic process & $3,10 \mathrm{E}-05$ & $4,10 \mathrm{E}-03$ \\
\hline & response to wounding & $2,90 \mathrm{E}-06$ & $1,30 \mathrm{E}-03$ \\
\hline & homeostatic process & $1,70 \mathrm{E}-03$ & $5,50 \mathrm{E}-02$ \\
\hline & immune response & $3,70 \mathrm{E}-04$ & $2,40 \mathrm{E}-02$ \\
\hline & cell death & $3,10 \mathrm{E}-03$ & $8,30 \mathrm{E}-02$ \\
\hline & Top 14 out of 145 & & \\
\hline
\end{tabular}




\section{Supplemental materials and methods}

\section{Polymerase chain reaction (PCR)}

Total RNA from additional WJ stem cell donors $(n=5)$ and the NT2/D1 cell line was isolated using the High Pure RNA Isolation Kit (Roche Diagnostics, Vilvoorde, Belgium) according to manufacturer's instructions. RNA quality was assessed with a Nanodrop 2000 spectrophotometer (ThermoFisher Scientific, Waltham, MA, USA) according to standard procedures. $1 \mu \mathrm{g}$ of RNA was reverse transcribed to cDNA using the Reverse transcription system (Promega, Leiden, The Netherlands) according to manufacturer's protocol. For each test, a $20 \mu \mathrm{l}$ reaction volume was used containing $19 \mu 1$ master mix consisting of nuclease-free water (Promega), $2 \mu 1$ 10x PCR buffer $+\mathrm{MgCl}_{2}$ (Invitrogen ${ }^{\mathrm{TM}}$, ThermoFisher Scientific), $10 \mathrm{mM}$ forward (fw) and reverse (rev) primers (Eurogentec, Seraing, Belgium), $0.2 \mu 1 \mathrm{dNTP}$ mix $\left(20 \mathrm{mM}\right.$, Invitrogen $\left.{ }^{\mathrm{TM}}\right), 0.16 \mu \mathrm{l} \mathrm{Taq}$ polymerase $\left(5 \mathrm{U} / \mu \mathrm{l}\right.$; Invitrogen $\left.{ }^{\mathrm{TM}}\right)$ and $1 \mu \mathrm{l}$ of sample cDNA. As a negative control $1 \mu$ of nuclease-free water was added instead of cDNA. The PCR program consisted of a pre-denaturion step of 1 minute at $95^{\circ} \mathrm{C}$ followed by 40 cycles of 30 seconds at $95^{\circ} \mathrm{C}$ (denaturation), 30 seconds at $56 / 60^{\circ} \mathrm{C}$ (OCT4-SOX2 / NANOG annealing respectively) and 1 minute at $72^{\circ} \mathrm{C}$ (elongation). Next, a final elongation step was performed for 10 minutes at $72^{\circ} \mathrm{C}$ after which the samples were held at $4{ }^{\circ} \mathrm{C}$ until gel electrophoresis. Primers for POU5F1 (OCT4), SOX2, and NANOG were as follows: POU5F1 5'AGCCCTCATtTCACCAGGCC-3' (fw) and 5'-TGGGACTCCTCCGGGTTTTG-3' (rev); SOX2 5'-AGAAGCGGCCGTtCATCGAC-3' (fw) and 5'-TGCTGATCATGTCCCGGAGGT-3' (rev); NANOG 5'-CAGAAGGCCTCAGCACCTAC-3' (fw) and 5'-GAATTTGGCTGGAACTGCAT-3' (rev). The PCR products or a 100 bp DNA ladder (Invitrogen ${ }^{\mathrm{TM}}$, ThermoFisher Scientific) were mixed with Orange G (Sigma-Aldrich, St. Louis, MO, USA) and separated by electrophoresis using a $2 \%$ agarose gel in Tris-acetate-EDTA buffer containing ethidium 
bromide (1/10.000; Bio-Rad, Hercules, CA, USA). Gels were imaged using a Gel Doc XR system (Bio-Rad).

6

7

8

9

10

11

12

13

14

15

16

17

18

19

20

21

22

23

24

25

26

27

28

29

30

31

32

33

34

35

36

37

38

39

40

41

42

43

44

45

46

47

48

49

50

51

52

53

54

55

56

57

58

59

60 